\title{
The Ilopango Tierra Blanca Joven (TBJ) eruption, El Salvador: Volcano-stratigraphy and physical characterization of the major Holocene event of Central America
}

\author{
Dario Pedrazzi ${ }^{\text {a,* }}$, Ivan Sunye-Puchol ${ }^{\mathrm{b}}$, Gerardo Aguirre-Díaz ${ }^{\mathrm{b}}$, Antonio Costa ${ }^{\mathrm{c}}$, Victoria C. Smith ${ }^{\mathrm{d}}$, \\ Matthieu Poret ${ }^{\mathrm{c}}$, Pablo Dávila-Harris ${ }^{\mathrm{e}}$, Daniel P. Miggins ${ }^{\mathrm{f}}$, Walter Hernández ${ }^{\mathrm{g}}$, Eduardo Gutiérrez ${ }^{\mathrm{g}}$ \\ a ICTJA, CSIC, Group of Volcanology, SIMGEO UB-CSIC, Institute of Earth Sciences Jaume Almera, Lluis Sole i Sabaris s/n, 08028 Barcelona, Spain \\ b Centro de Geociencias, Universidad Nacional Autónoma de México, Blvd. Juriquilla 3001, Campus UNAM, Querétaro 76230, Mexico \\ c Istituto Nazionale di Geofisica e Vulcanologia, INGV-Bologna, Via Donato Creti, 12, 40100 Bologna, Italy \\ ${ }^{\mathrm{d}}$ Research Laboratory for Archaeology and the History of Art, University of Oxford, 1-2 South Parks Road, Oxford OX1 3TG, UK \\ e División de Geociencias Aplicadas, IPICYT, San Luis Potosí 78216, Mexico \\ ${ }^{f}$ College of Earth, Ocean and Atmospheric Sciences, Oregon State University, 104 CEOAS Administration Building, 101 SW 26th St, Corvallis, OR 97331, United States of America \\ ${ }^{g}$ Gerencia de Geología del Observatorio Ambiental, Ministerio de Medio Ambiente y Recursos Naturales MARN, San Salvador 76230, El Salvador
}

\section{A R T I C L E I N F O}

\section{Article history:}

Received 29 August 2018

Received in revised form 7 March 2019

Accepted 8 March 2019

Available online 16 March 2019

\section{Keywords:}

Pyroclastic Density Currents

Co-ignimbrite

Tephra fallout

Tephra dispersal modelling

Ilopango caldera

\begin{abstract}
A B S T R A C T
The Ilopango caldera is the source of the large Tierra Blanca Joven (TBJ) eruption that occurred about 1.5 ka years ago, between ca. AD270 and AD535. The eruption dispersed volcanic ash over much of the present territory of El Salvador, and pyroclastic density currents (PDCs) extended $40 \mathrm{~km}$ from the volcano. In this study, we document the physical characteristics of the deposits from all over El Salvador to further constrain the eruption processes and the intensity and magnitude of the different phases of the eruption. The succession of deposits generated by the TBJ eruption is made of 8 units. The eruption started with PDCs of hydromagmatic origin (Unit $\left.A_{0}\right)$, followed by fallout deposits (Units A and B) that are $<15 \mathrm{~cm}$ thick and exposed in sections close to the Ilopango caldera (within 10-15 km). The eruption, then, transitioned into a regime that generated further PDCs (Units CF), these range from dilute to dense and they filled the depressions near the Ilopango caldera with thicknesses up to $70 \mathrm{~m}$. Deposits from the co-ignimbrite plume (Unit G) are the most widespread, the deposits are found in Guatemala, Honduras, Nicaragua, Costa Rica and the Pacific Ocean and cm-thick across El Salvador. Modelling of the deposits suggests that column heights were $29 \mathrm{~km}$ and $7 \mathrm{~km}$ for the first two fallout phases, and that the co-ignimbrite phoenix plume rose up to $49 \mathrm{~km}$. Volumes estimated for the fallout units are $0.15,0.8$ and $16 \mathrm{~km}^{3}$ dense rock equivalent (DRE) for Unit A, B and G respectively. The PDCs deposits volumes were estimated to be $\sim 0.5, \sim 3.3, \sim 0.3$ and $\sim 9.1 \mathrm{~km}^{3}$ DRE for Units C, D, E and F, respectively. The combined volume of TBJ deposits is $\sim 30 \mathrm{~km}^{3}$ DRE ( $\sim 58 \mathrm{~km}^{3}$ bulk rock), indicating that it was one of largest Holocene eruptions from Central America. This eruption occurred while Mayan populations were living in the region and it would have had a significant impact on the areas within tens of kilometres of the vent for many years to decades after the eruption.
\end{abstract}

(c) 2019 Elsevier B.V. All rights reserved.

\section{Introduction}

Large caldera volcanoes pose a significant hazard to populations that surround them. In order to understand the likelihood and type of further activity it is key that the deposits of previous eruptions are well studied. This study focuses on the thick deposits of the Tierra Blanca Joven (TBJ) eruption from Ilopango Caldera, El Salvador.

Ilopango Caldera (IC; Fig. 1), is a 13 by $17 \mathrm{~km}$ volcano-tectonic structure filled by an intra-caldera lake (Mann et al., 2004), recently

\footnotetext{
* Corresponding author.

E-mail address: dpedrazzi@ictja.csic.es (D. Pedrazzi).
}

interpreted as a strike-slip caldera by Saxby et al. (2016). The IC belongs to the San Salvador Extensional Step-over in the central part of the country (SSES; Fig. 1b; Garibaldi et al., 2016), which is in turn part of the El Salvador Fault Zone-ESFZ (Montero and Dewey, 1982; Siebert and Simkin, 2002; LaFemina et al., 2009; Corti et al., 2005; Turner Henry et al., 2007). The IC was formed and shaped by various eruptions, and older (pre-57 ka) pyroclastic deposits are related to previous caldera collapse episodes (Lexa et al., 2011; Aguirre-Díaz et al., 2017; Suñe-Puchol et al., 2019a, 2019b). There are only a few publications that detail the eruptions in the last $57 \mathrm{ka}$, i.e. the TB4, TB3 and TB2 eruptions (Rose et al., 1999; Kutterolf et al., 2008a, 2008b; Hernández, 2004; Hernández et al., 2012; Mann et al., 2004) and some recent studies have been carried out on the pre-57 ka 

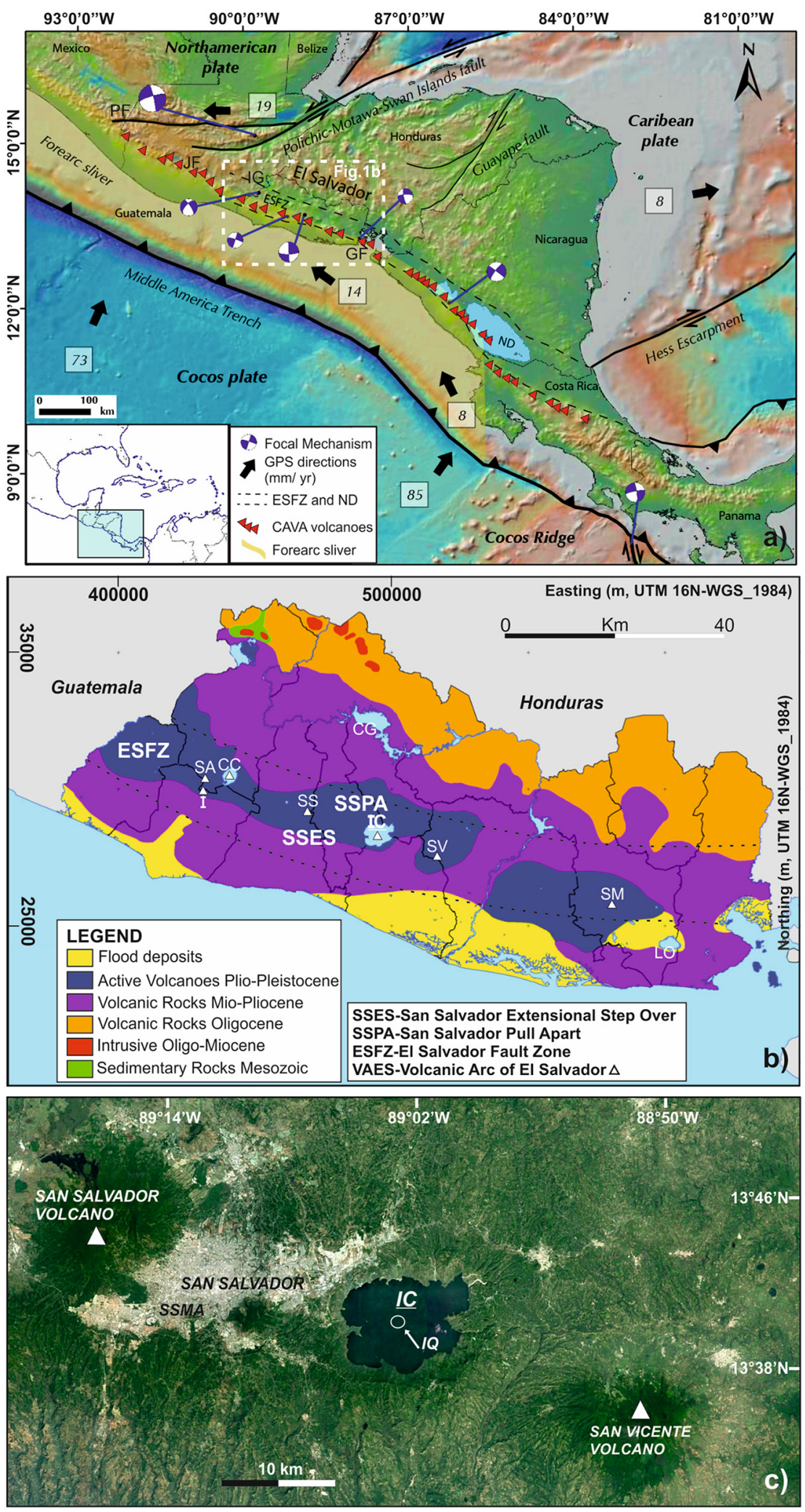

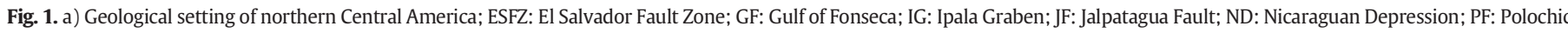

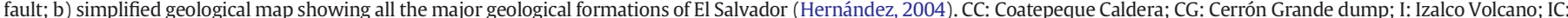

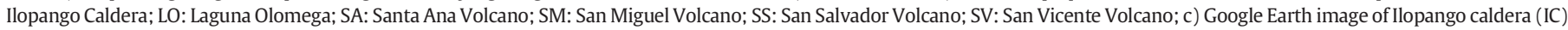
(US Depth of State Geographer 2018); SSMA: San Salvador Metropolitan area; IQ: Islas Quemadas.

ignimbrites of Ilopango (Hernández, 2004; Hernández et al., 2010; Lexa et al., 2011; Aguirre-Díaz et al., 2017; Suñe-Puchol et al., 2019a, 2019b). More studies focused respectively on the eruption of a dacitic dome that formed the Islas Quemadas in Ilopango Lake (IQ; Fig. 1c) in 1879 (Richer et al., 2004), and a subaquatic eruption in this lake (Mann et al., 2004). 
The last large explosive eruption of Ilopango volcano was the TBJ (Tierra Blanca Joven - white young earth), which is estimated to have erupted $\sim 30 \mathrm{~km}^{3}$ DRE of magma about $1.5 \mathrm{ka}$ years ago, between AD270 and AD535 (Dull et al., 2001, 2010). The TBJ was a cataclysmic eruption (Rolo et al., 2004) and is considered to be the largest in Central America since the ca. 84 ka Los Chocoyos-Guatemala eruption (Dull et al., 2010). Outside of the zone of devastation by the TBJ eruption, there was a much larger area of prolonged depopulation (10-150 years) following the TBJ eruption (Dull et al., 2001).

Presently, the area around IC is densely populated with about $3,000,000$ people living within $30 \mathrm{~km}$ of the caldera. The population density during most of the late Holocene in El Salvador has been the greatest of any mainland country in the Americas (Daugherty, 1969; Denevan, 1992; Lovell and Lutz, 1995; Wilkie and Guadalupe Ortega, 1997). Since the last eruption was in AD1879, IC is still considered active and, it poses a major risk for El Salvador and neighbouring countries. In order to contribute to the hazard assessment at IC, we conducted a detailed field mapping to further investigate the TBJ deposits with the aim of building on the previous work and accurately reconstructing the eruption sequence.

There have been several publications about the TBJ eruption deposits. They were first documented by Williams and Meyer-Abich (1955) and called "white earth" due to their peculiar white colour, although they were thought to originate from San Salvador Volcano. Further studies of IC deposits were carried out by the German Geological Mission (MGA) whilst they completed the 1:500,000 scale El Salvador Geological Map (Weber et al., 1974). They defined IC and divided the proximal deposits into Units s4 (TBJ deposits) and s3'a (TB4, TB3 and TB2 eruptions) as part of the San Salvador Formation. Later, Hart (1981) worked on the detailed stratigraphy of the TBJ deposits and identified two important eruptive stages; T1 and T2, whose products are subdivided into six units and associated with different eruptive phases. Subsequently, Hart and Steen-McIntyre (1983) described the stratigraphy and distribution of the TBJ tephra and Vallance and Houghton (1998) revised the stratigraphy of Hart and Steen-McIntyre (1983) and labelled the stratigraphic units, characterizing them lithologically and refining associated eruptive processes. Recent works on TBJ by Hernández (2004) identified new ignimbrites (Alpha, Beta, and Grey) and detailed the characteristics of each unit in more detail.

Despite all this studies, a detailed stratigraphic survey including mapping and reconstruction of eruptive dynamics was still lacking. This study presents new field descriptions, petrographic observations, major element glass geochemistry, granulometric data for the TBJ deposits, and uses these data to further understand transport/depositional mechanisms and the corresponding eruption dynamics of the TBJ eruption. Moreover, the physical parameters of the eruption were determined, including the total erupted mass, the height of the eruptive columns, the emission rate and, above all, reconstruct the distribution of the TBJ deposit using models and field observations. In particular, the stratigraphic and granulometric data obtained in the field were used to model the distribution of the TBJ tephra, including the dispersion of the finest ash that covered vast areas (thousands of $\mathrm{km}^{2}$ ).

\section{Geological setting}

\subsection{Central America and El Salvador geodynamic and geology}

El Salvador is located in North Central America, on the Pacific margin of the Caribbean Plate (Fig. 1a). To the north, this plate interacts with the North American plate with a relative velocity between plates of $19 \mathrm{~mm} /$ year (DeMets et al., 2000; Guzmán-Speziale et al., 2005; Funk and Mann, 2009). Towards the west of El Salvador, the relatively young Cocos Plate (<25 Ma; Protti et al., 1995; Barckhausen et al., 2001) subducts towards the NE under the Caribbean plate along the Middle America Trench, at a speed of 73-85 mm/year (Dixon, 1993; DeMets, 2001).

The highest rate of continental tectonic deformation in El Salvador occurs in the El Salvador Fault Zone (ESFZ), a narrow E-W zone of right lateral faulting connected by pull-aparts, that extends for $>150 \mathrm{~km}$ (Martínez-Díaz et al., 2004; Fig. 1a) from Guatemala, where it is known as the Jalpatagua Fault (JF), to the Nicaragua Depression (ND) (Canora et al., 2012). These faults are sub-parallel and affect volcanic products of Pleistocene-Holocene age (Corti et al., 2005). Geological and seismological analyses suggest that ESFZ is not laterally continuous and it has been subdivided into different sections (Martínez-Díaz et al., 2004; Corti et al., 2005).

The chain of volcanoes along the Central American Volcanic Arc (CAVA; Fig. 1a) has been developing since the Tertiary (DeMets, 2001; Mann, 2007; Carr et al., 2007) and is part of the Pacific Ring of Fire (Simkin and Siebert, 1994; Carr et al., 2007; Saxby et al., 2016). The CAVA extends for $>1000 \mathrm{~km}$ from the southeast of Mexico to the central valley of Costa Rica and defines an abrupt continental volcanic front located between 165 and $190 \mathrm{~km}$ from the Middle America Trench (Fig. 1a). Volcanoes of Panama are excluded from the CAVA as they are associated with the subduction of the Nazca Plate below the Caribbean, which makes them distinct in composition and activity relative to those in the CAVA (Carr et al., 2007).

Volcanism of the Volcanic Arc of El Salvador (VAES) constitutes one of the most active segments of the CAVA. VAES includes 21 active volcanoes, three of which have erupted in the last century: Santa Ana-SA, Izalco-I, San Salvador-SS and San Miguel-SM (Fig. 1b; Siebert and Simkin, 2002). Deposits from these volcanoes, together with volcanic rocks of ages ranging from the Cenozoic to the present, constitute most of the geology of El Salvador (Fig. 1b).

\subsection{Ilopango caldera}

The IC (Fig. 1c) is located $<10 \mathrm{~km}$ from San Salvador City and it forms part of the same eruptive lineament as the San Salvador and San Vicente volcanoes (Fig. 1b). IC is located directly above faults in the San Salvador and San Vicente ESFZ segments within the San Salvador Pull-Apart (SSPA; Garibaldi et al., 2016), which is a tectonic structure-oriented NW-SE, with right trans-tensive dynamics, parallel to the Mesoamerican trench. The transforming faults of the graben/pull-apart seem to control the morphology of IC, its formation and its volcanic eruptions (Sofield, 2004; Suñe-Puchol et al., 2019a), as described for other Graben Calderas (Aguirre-Díaz, 2008). Several authors, in their study of volcanism in southern El Salvador, noticed that the IC was a volcanictectonic depression controlled by the faults of an ancient graben (Williams and Meyer-Abich, 1955; Golombek and Carr, 1978; Hutton and Reavy, 1992; Sofield, 2004; Aguirre-Díaz and Martí, 2015; Aguirre-Díaz et al., 2016, 2017). Recently, Saxby et al. (2016) interpreted IC as a strike-slip caldera. IC was the result of several collapses associated to large explosive ignimbrite-forming eruptions (Suñe-Puchol et al., 2019a, 2019b) as previously suggested by Williams and Meyer-Abich (1955). The topographic edge of IC has several semicircular bays (Fig. 1c), which are evidence for multiple collapse events (Lexa et al., 2011).

\section{Methods}

Field mapping was carried out over an area of about $20,000 \mathrm{~km}^{2}$ across El Salvador to reconstruct the stratigraphy of the TBJ deposits and the stratigraphic relationships with other eruptive deposits. The characteristics of the deposits were recorded including grading, colour, sorting, apparent component content (juvenile and lithic fragments), and primary sedimentary structures. The nomenclature used in this study for the bed thickness, grain size and sorting of the pyroclastic deposits follows that proposed by Sohn and Chough (1989). The classification of the primary volcaniclastic deposits follows White and Houghton (2006) and the nomenclature for volcanic stratigraphy is based on Martí et al. (2018), adopting the same criteria as Suñe-Puchol et al. (2019a, $2019 b)$ for the previous Ilopango eruptions. A total of 82 stratigraphic sections were measured, but we focus here on 21 outcrops that we 
consider representative of the whole succession, and its spatial variations and preservation of deposits.

The geographical coordinates of the locations, stratigraphic sections and sampling points were recorded using a portable Garmin Dakota-20 GPS (precision of $\sim 3 \mathrm{~m}$ ) and quoted on the UTM projection Datum: D_WGS_1984, zone 16 N. All this local information is reported in Supplementary Material 1 . All the georeferenced data were managed and processed using the open source software Quantum GIS (Las Palmas; https://www.qgis.org/en/site/).

Thicknesses of the deposits and specific units were measured to create a database (see Supplementary Material 1) for tephra dispersal simulations (Macedonio et al., 2005). Tephra dispersal from virtual sources in an eruption column was simulated using the HAZMAP model, which solves equations for advection, diffusion and sedimentation of tephra particles in two dimensions (Macedonio et al., 2005). We followed an approach similar to Matthews et al. (2012) but used the Total Grain Size Distributions (TGSDs) (Bonadonna and Houghton, 2005) phases determined through the Voronoi Tessellation method, that we estimated for the different phases using data collected in this study. The granulometry data used to generate the TGSDs are available in Supplementary Material 2. Isopach maps were generated by modelling the ash deposition in terms of mass loading $\left(\mathrm{kg} / \mathrm{m}^{2}\right)$ and these were converted into thicknesses using a bulk density of $1000 \mathrm{~kg} / \mathrm{m}^{3}$. In addition to the volumes, the solution of the inverse problem (Costa et al., 2009; Matthews et al., 2012) allowed us to estimate column heights, from which, by using the results of Mastin et al. (2009) and Bonadonna and Costa (2013), we assessed the corresponding Mass Eruption Rates (MER) for each unit. The volume estimations of the PDCs units were determined using the Delaunay triangulation method (Macedonio and Pareschi, 1991) that is particularly suitable for the reconstruction of volume between geological horizons and the interpolation of bivariate data, when function values are available at irregularly-spaced data points, as in the case of geological outcrops.

A binocular microscope was used to determine the main petrographic and textural characteristics of the juvenile components. In addition, petrographic analyses were carried out in order to identify the mineralogy and general composition of the studied deposits. Thin sections were produced at Wagner Petrographic LLC, a professional company of Lindon, Utah (USA).

Granulometric analyses were performed at the MARN (Ministerio de Medio Ambiente y Recursos Naturales) facilities of El Salvador Government and the Physical Volcanology Laboratory of Centro de Geociencias, Universidad Nacional Autonoma de Mexico (UNAM) in JuriquillaQuerétaro (Mexico). Representative levels of each stratigraphic unit were sampled and analysed (141 samples in total; Fig. 2 and Supplementary material 2) for grain-size distribution and componentry. Grain-size analysis were performed by dry sieving at 1 phi $(\Phi)$ intervals through sieves with aperture sizes ranging from 64 to $0.25 \mathrm{~mm}$ ( -6 Ф to $3 \Phi$, where $\Phi=-\log _{2} d$ with $d$ is the diameter in $\mathrm{mm}$ ) and by wet sieving through a MicroTec Analisette22 Fritsch from $0.125 \mathrm{~mm}$ to $<0.01 \mathrm{~mm}$ ( $4 \Phi$ to $>10 \Phi)$. The weight percentages of the sieved fractions were calculated and then plotted as cumulative curves to give grain-size distribution. All data from grain-size analysis are reported in Supplementary Materials 2, 3 and 4. The proportion of juveniles from $-5 \Phi$ to $0 \Phi$ was defined by hand picking and from $0 \Phi$ to 2 Ф using a binocular microscope and image analysis techniques (e.g. ImageJ software; https:// imagej.nih.gov/ij/). This point-counting method allows identifying the different components of each particle-size class using binocular microscope pictures. Modal proportions of juvenile pumice and accidental lithic fragments are reported in Supplementary Material 5.

Whole rock pumice geochemical analyses for major elements, trace and rare earth-elements (REE) (Table 2) were measured at the CGEO LEI laboratory (trace and REE, with an ICP-MS) and at Instituto de Geología of UNAM (major and trace elements, X RIGAKU ZSX Primus II spectrometer), following standard sample preparation and analytical techniques (Bernal and Lozano-Santacruz, 2005).
Electron probe X-ray microanalysis for mineralogy was performed using a JEOL JXA-8230 electron microprobe at the Scientific and Technological Centers (Universitat de Barcelona). Wavelength-dispersive analyses of silicates were conducted using a $20 \mathrm{kV}$ accelerating voltage and $15 \mathrm{nA}$ current and with a focused beam. Glasses were analysed using a $6 \mathrm{nA}$ current with a defocused 5-10 $\mu \mathrm{m}$ spot. Counting times were $10 \mathrm{~s}$ peak and $10 \mathrm{~s}$ background. A range of natural and synthetic standards was used for calibration. The correction model XPP was used to convert X-ray intensity ratios into concentrations. Data are included in Supplementary Material 6.

The major element compositions of the matrix glass of the TBJ were determined using wavelength-dispersive electron probe microanalysis (EPMA) in the Research Laboratory for Archaeology and the History of Art (RLAHA) at the University of Oxford. Analyses were carried out on samples from all units, A to G, and distal deposits located up to $130 \mathrm{~km}$ from the caldera. The EPMA of the TBJ glasses were acquired using an accelerating voltage of $15 \mathrm{kV}$, beam current of $6 \mathrm{nA}$, and 10$\mu \mathrm{m}$-diameter beam. The count times on peak were: $30 \mathrm{~s}$ for $\mathrm{Si}, \mathrm{Al}, \mathrm{Fe}$, $\mathrm{Ca}, \mathrm{K}$ and Ti; $50 \mathrm{~s}$ for $\mathrm{Cl}$ and $\mathrm{Mn}$; $60 \mathrm{~s}$ for P; and $12 \mathrm{~s}$ for Na, and background counts were collected for the same amount of time but split to positions either side of the peak. The PAP absorption correction method was used for quantification and the oxide compositions quoted assume stoichiometry. The electron probe was calibrated for each element using well-characterized mineral standards, which was verified by analysing MPI-DING reference glasses (Jochum Klaus et al., 2006). These MPIDING glasses were used as secondary standards during each analytical run, and this data is included in the Supplementary Material 7 as they demonstrate the accuracy and precision of the TBJ datasets. All the glass analyses presented have been normalized to $100 \%$ to account for variable hydration and allow different samples to be compared, and all the raw compositional data can be accessed in Table 3.

\section{Characteristics of the pyroclastic succession}

Proximal TBJ member products (0-10 km from the caldera) are exposed inside and close to the caldera with a maximum observed thickness of $\sim 60 \mathrm{~m}$ (Supplementary Material 1). The TBJ member can be divided in 8 units that were labelled alphabetically from base to top ( $A_{0}-G$; Fig. 2). Due to differences in dispersal patterns, lateral facies variations and surface erosion, the complete stratigraphy was reconstructed from a large number of individual outcrops. Simplified stratigraphic logs of 21 localities are shown in Fig. 2. The TBJ member consists of initial pumice lapilli-supported grain deposits and later of several units made of a coarse and fine ash, matrix-supported massive deposits with pumice lapilli and lithics interbedded with laminated levels of lapilli (i.e. ILO 18 and ILO22; Fig. 2). All these deposits were mapped across several dozens of $\mathrm{km}$ from the caldera rim. The medial succession can be observed up to $30-40 \mathrm{~km}$ from the caldera rim, where the best exposures are found on the southern slopes of IC (i.e. ILO 8 and ILO130; Fig. 2). The last unit, which comprises massive finegrained deposits, is observed in medial exposures and distal ones that are $>100 \mathrm{~km}$ from the caldera (i.e. ILO289 and ILO302; Fig. 2). Deposits from the TBJ eruption are characterized as being white soft and easily erodible, generating "badlands" type scarps (Šebesta, 2007). Most of the San Salvador Metropolitan Area (Fig. 1c) has been built on the TBJ tephra deposits.

\subsection{Unit $A_{0}$}

$A_{0}$ is the first unit in the TBJ succession of deposits (stratigraphic log 22 in Fig. 2), which is observed in medial (10-40 km from the vent) outcrops mainly to the south of the caldera. Thickness ranges from 2 to $4 \mathrm{~cm}$ (Supplementary Material 1) and the deposits are characterized by poorly-sorted, thinly bedded or laminated, moist beds of rounded dense, glassy coarse and fine pumice ash with accidental lithic fragments. The deposit usually rests directly upon a paleosol or older, 


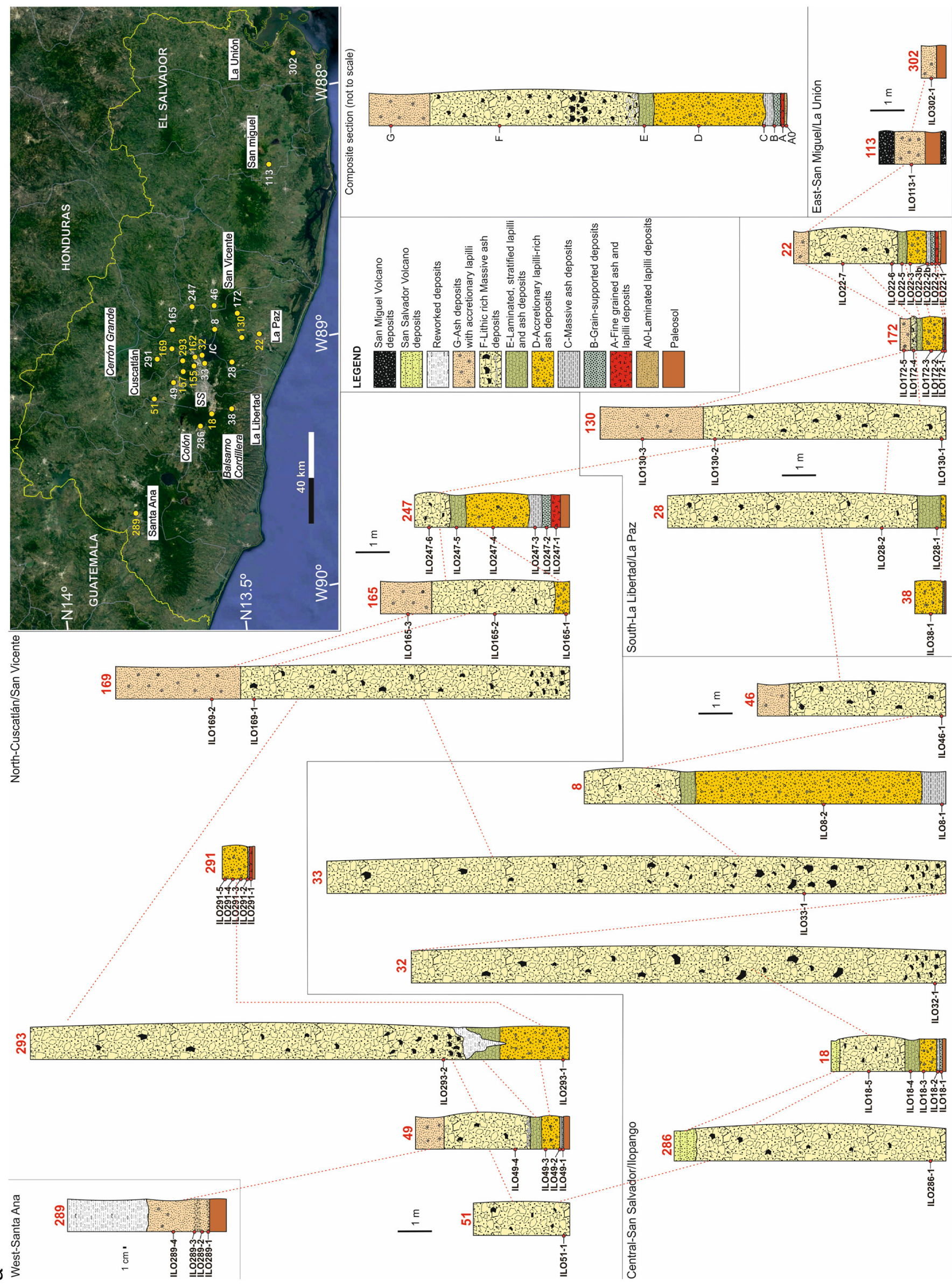


b
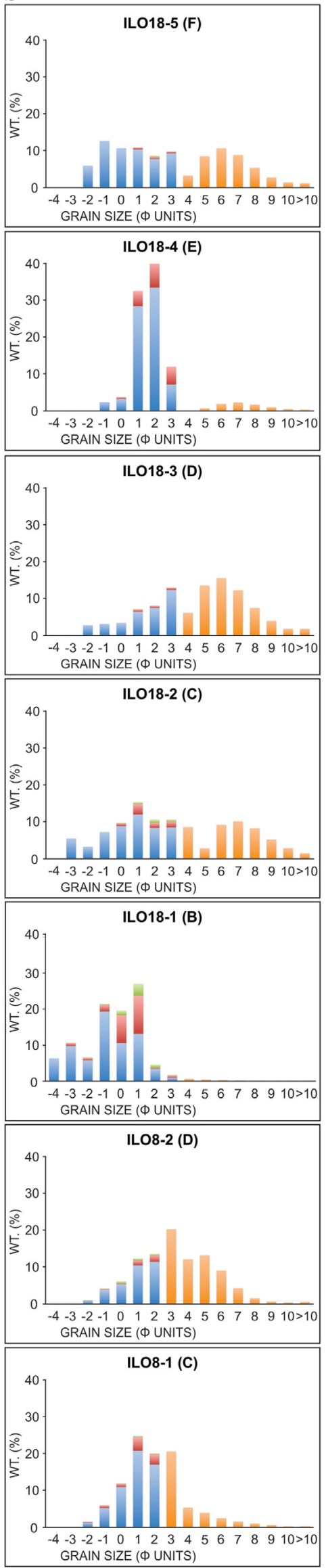

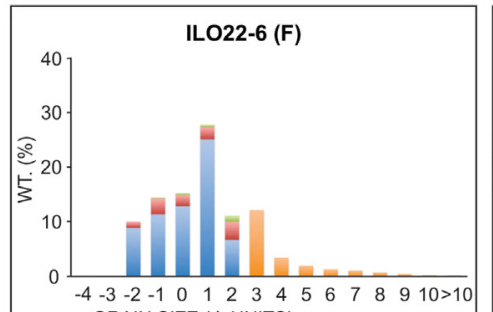
GRAIN SIZE ( $\Phi$ UNITS)
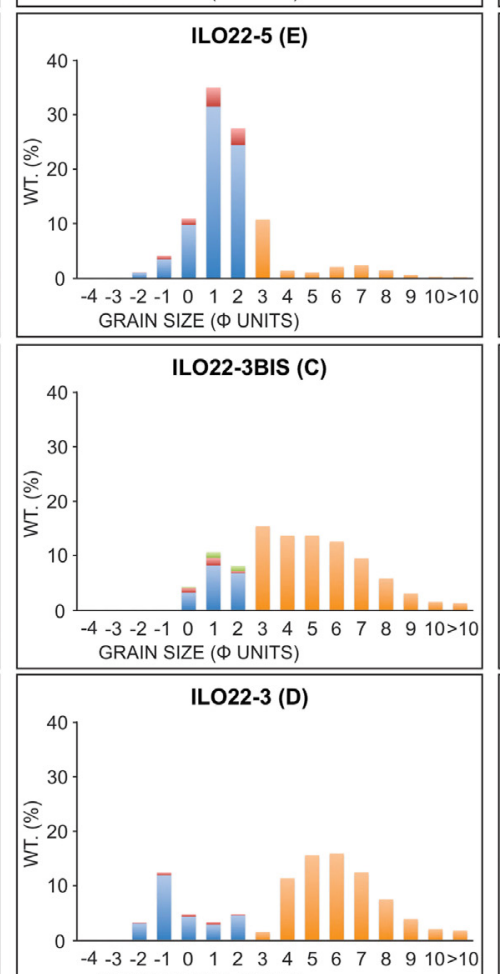
GRAIN SIZE ( $\Phi$ UNITS)
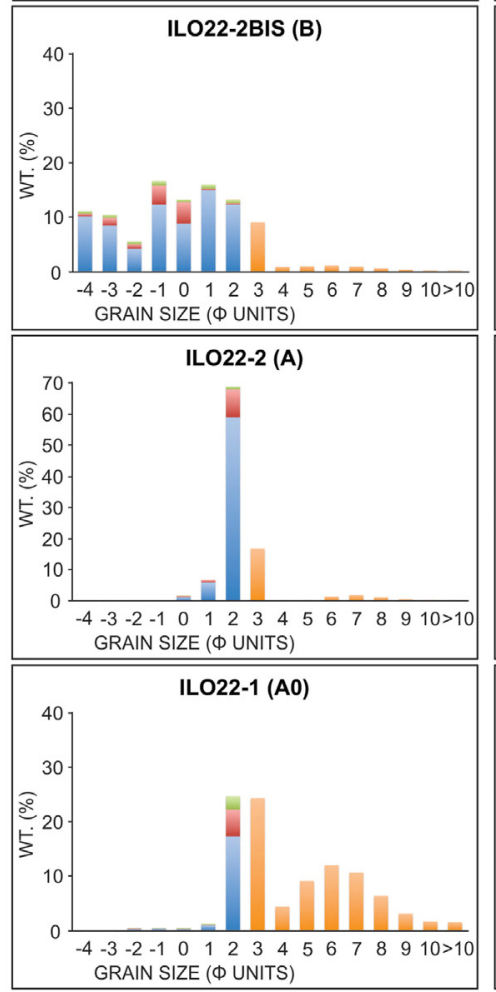

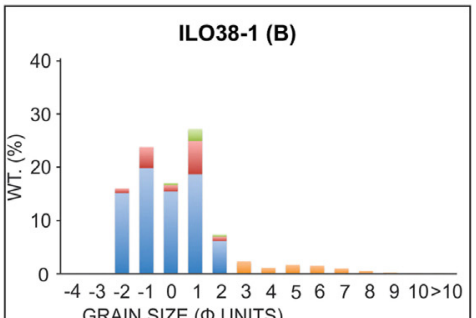

GRAIN SIZE ( $\$$ UNITS)

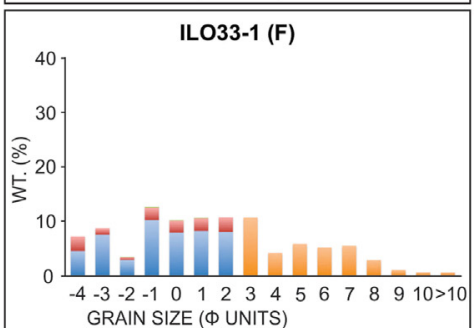
GRAIN SIZE (Ф UNITS)

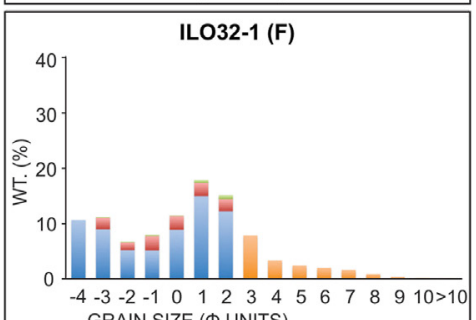

GRAIN SIZE ( $\Phi$ UNITS)

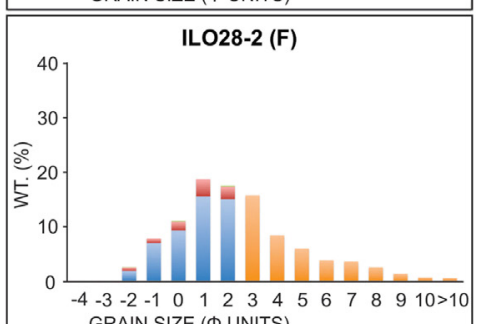

GRAIN SIZE (Ф UNITS)
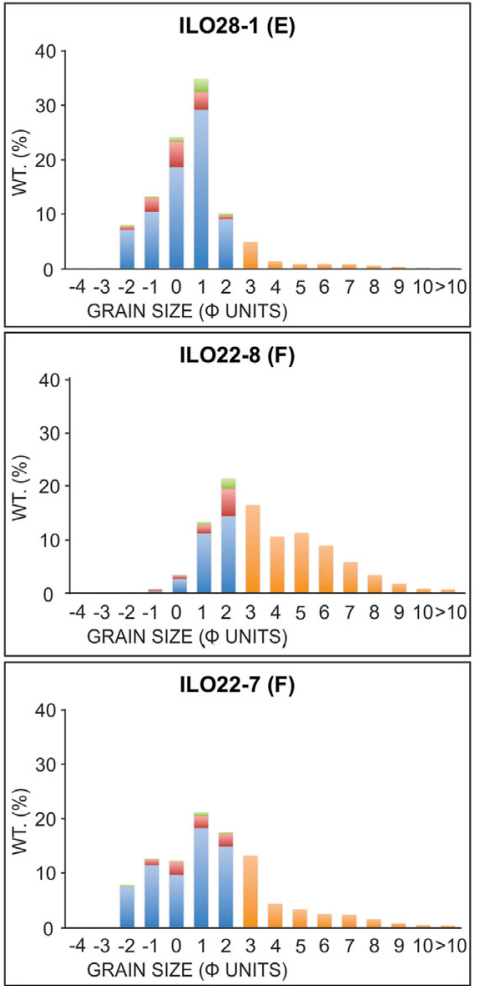
C
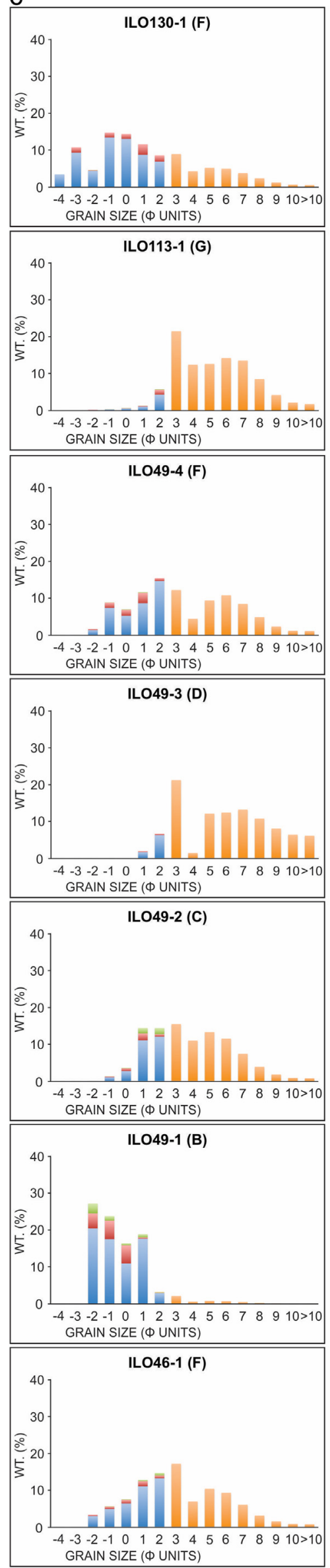
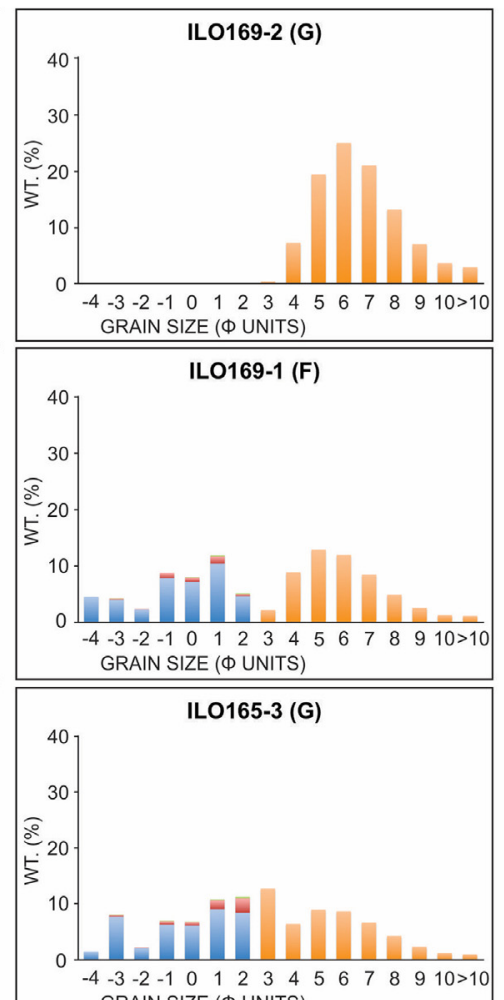
GRAIN SIZE ( $\Phi$ UNITS)

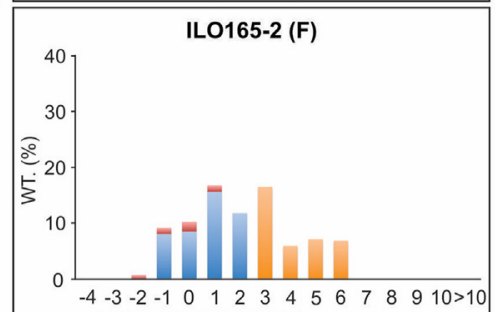

GRAIN SIZE ( $\Phi$ UNITS)
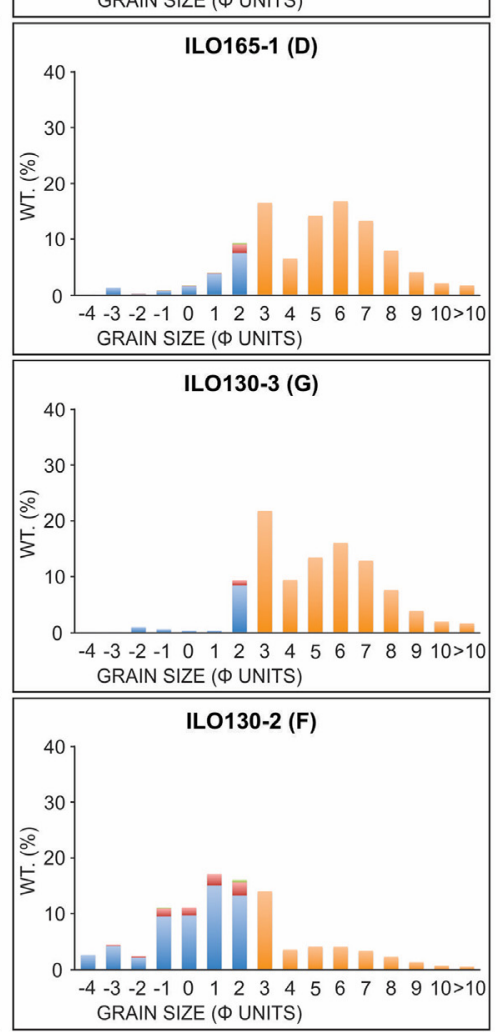

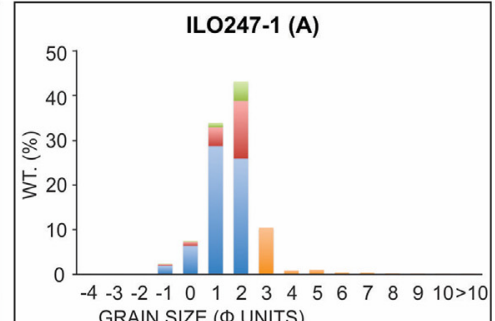

GRAIN SIZE ( $\Phi$ UNITS)
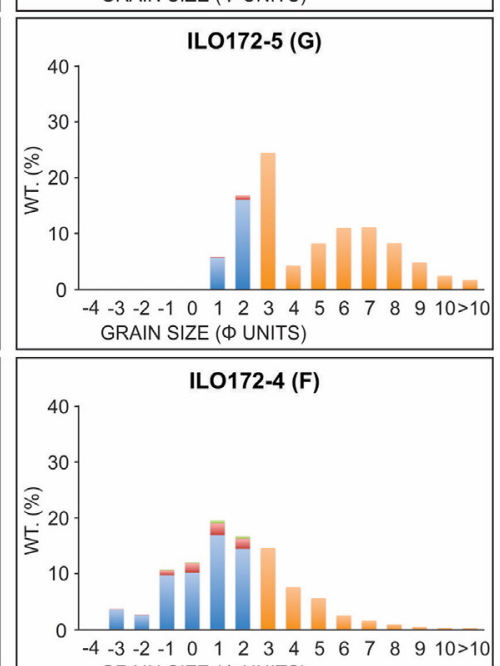
GRAIN SIZE ( $\Phi$ UNITS)

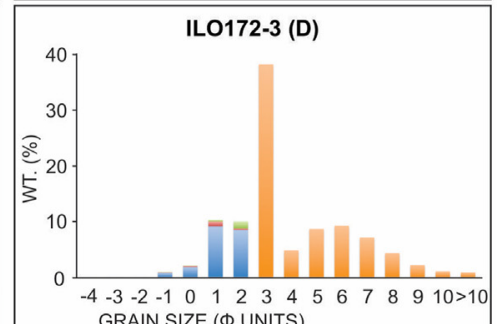

GRAIN SIZE ( $\$$ UNITS)
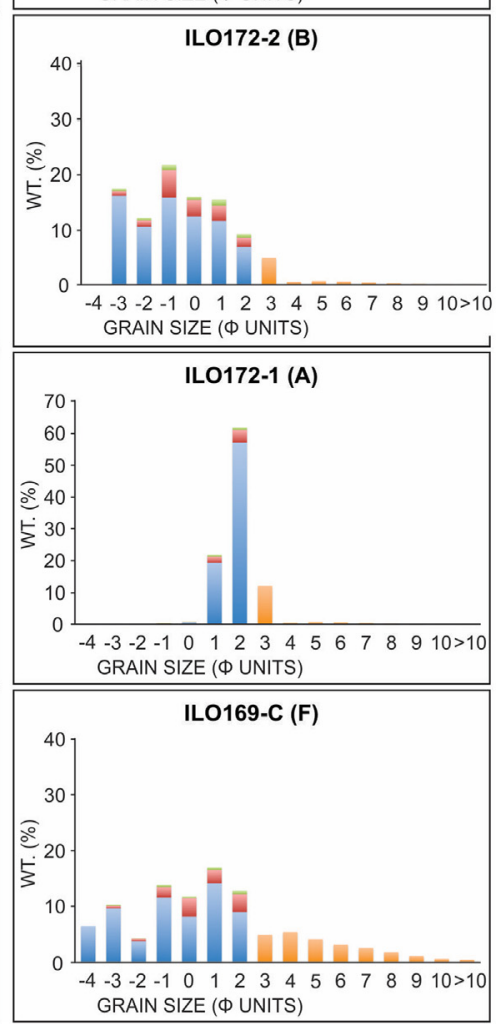
d
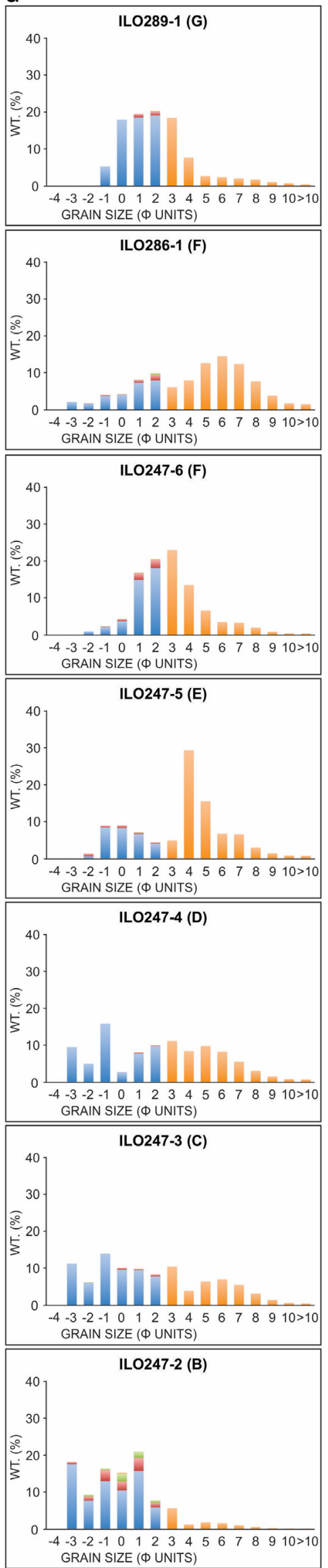

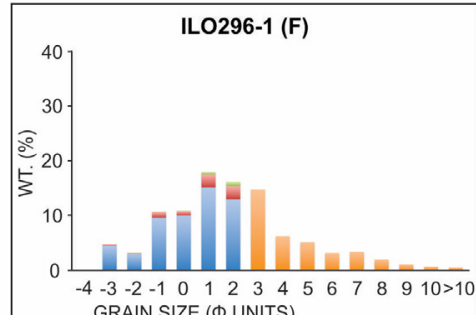
GRAIN SIZE ( $\Phi$ UNITS)

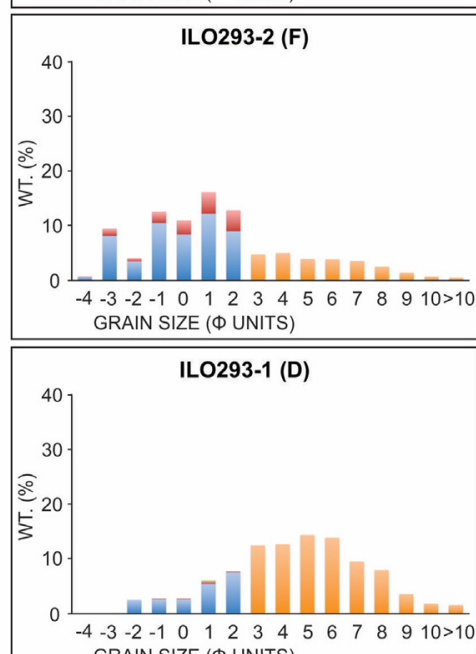
GRAIN SIZE ( $\Phi$ UNITS)

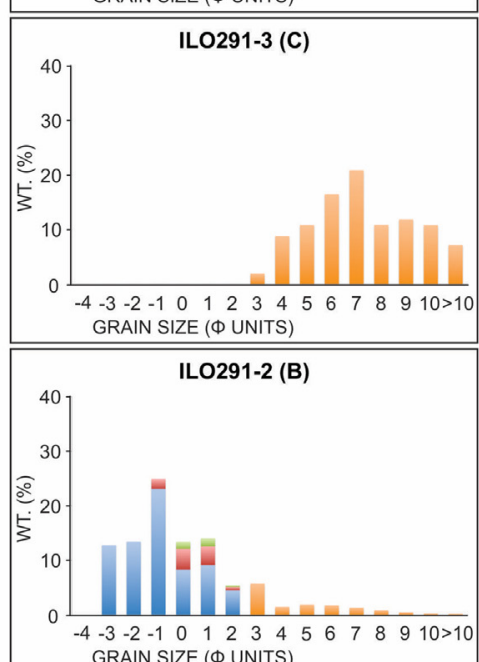
GRAIN SIZE ( $\Phi$ UNITS)
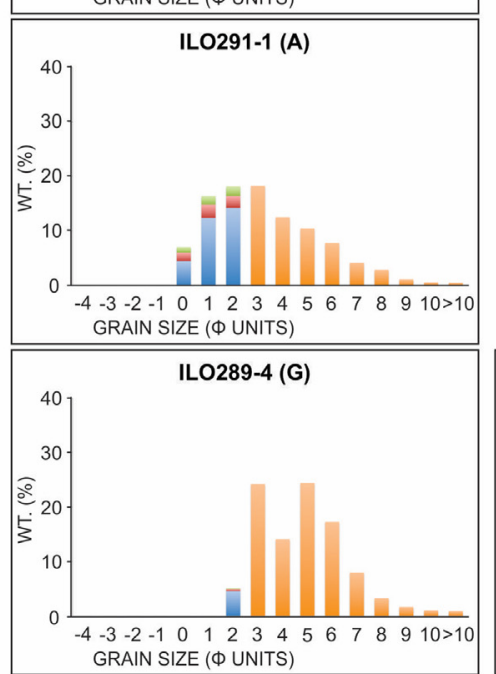

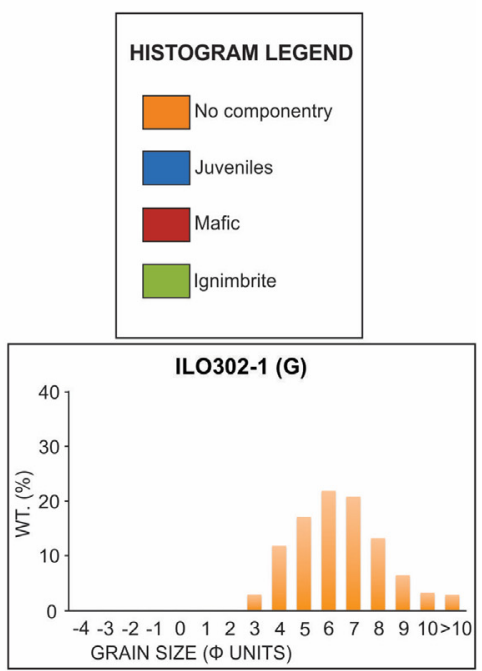


weathered pre-caldera lavas. At the outcrop scale, there are lateral variations in the thickness and number of beds, with pinch and swell structures and locally erosive basal contacts (Fig. 3a,b).

\subsection{Unit A}

Unit A (stratigraphic logs 22, 172, 247, 291 in Fig. 2) outcrops in different points around IC, but mainly in the eastern and southern sectors at medial locations. It shows thicknesses from 3 to $14 \mathrm{~cm}$ (Supplementary Material 1) and is characterized by massive well-sorted thin to medium coarse angular pumice ash beds (Fig. 3a,b) with ash-sized lithic fragments. A planar contact separates it from the underlying Unit $A_{0}$.

\subsection{Unit B}

Unit B (stratigraphic logs 18, 22, 38, 49, 172, 247, 291 in Fig. 2) is characterized by moderately sorted, massive thin beds of angular pumice lapilli and lithics with no ash (Fig. 3c). Thicknesses vary from 1 to $\sim 5 \mathrm{~cm}$ (Supplementary Material 1). This deposit shows sometimes yellowish colour due to the pigmentation and cementing of iron oxides by contact with the underlying paleosol. It appears in several outcrops at proximal and medial locations.

\subsection{Unit C}

Unit C (stratigraphic logs 8, 18, 22, 49, 247 in Fig. 2) is only preserved at a few outcrops in proximal and medial locations. It has a peculiar grey-yellowish colour (Fig. 3a) and is a well-sorted, matrix-supported deposit with light stratification of pumice fragments with scattered accretionary lapilli and hydrothermally altered lithics. Observed thicknesses range from a few $\mathrm{cm}$ up to $10 \mathrm{~m}$ in some depressions (Supplementary Material 1).

\subsection{Unit $D$}

Well-sorted, massive, lithic-poor ash rich deposit (Fig. 3d). Unit D outcrops at proximal and medial locations (stratigraphic $\log 8,18,22$, 28, 38, 49, 172, 247, 291, 293 in Fig. 2). The intermediate and distal ( $>40 \mathrm{~km}$ from the caldera) facies of this unit are quite unconsolidated with a fine ash matrix and dispersed pumice juvenile fragments (Fig. 3ei) and with slight variations between one horizon and another. At proximal locations the deposits are more cemented with a coarse ash matrix and containing beds that show a strong enrichment of millimetric accretionary lapilli (Fig. 3eii). At some outcrops, the deposit shows planar stratification. The maximum measured thickness of the Unit D is about $8 \mathrm{~m}$ (Supplementary Material 1).

\subsection{Unit E}

Unit E consists of doublets of thin to medium thick massive and laminated beds of rounded lapilli and coarse ash pumice (Fig. 3d,f). The unit outcrops at proximal and medial locations from the caldera (stratigraphic $\operatorname{logs} 8,18,22,28,49,172,247,293$ in Fig. 2). It represents a good stratigraphic marker of the TBJ eruption and to differentiate between Units D and F (Fig. 3d). The massive deposits are light coloured and composed of unconsolidated thick ash with pumice thin lapilli and lithics. The laminated deposits constitute very fine, well-sorted ash, that is light brown and dark brown when wet. It is commonly quite consolidated and rich in glass fragments and crystals. Locally, these deposits show folding that is characteristic of soft sediments
(Fig. 3g). The maximum measured thickness is $1 \mathrm{~m}$ (Supplementary Material 1).

\subsection{Unit F}

Unit F is composed of chaotic, massive, poorly-sorted, non-welded, light-coloured to light beige (Fig. 3d) with thickness up to about 60-70 m thick (Supplementary Material 1). Unit F outcrops at both proximal and medial locations (stratigraphic $\operatorname{logs} 8,18,22,28,32,33$, $46,49,51,130,165,169,172,247,286,293$ in Fig. 2) and found up to $40 \mathrm{~km}$ from the caldera. To the north, the deposits extend away from the caldera for at least $\sim 35 \mathrm{~km}$ and outcrop close to Cerrón Grande (Fig. 2). To the west, deposits cover part of San Salvador Volcano (Fig. 2), reaching a maximum height of $930 \mathrm{~m}$ (1,740 $\mathrm{m}$ a.s.l.). Deposits were also found close to the Municipality of Colón (Fig. 2), where they achieve a distance of $\sim 40 \mathrm{~km}$. Towards the southern part (Balsamo Cordillera; Fig. 2), deposits outcrop along the old channels of rivers and streams reaching distances of $>30 \mathrm{~km}$. East of IC, Unit F was recognized up to 30-35 km away, close to the San Vicente Volcano (Fig. 2). The deposits in the proximal outcrops show a coarse ash matrix with abundant centimeter- and decimeter-sized pumice and lithic fragments (Fig. 3h,i). Visibly mingled pumice with dark to light grey bands within the white pumice are found in unit $\mathrm{F}$ at very proximal sites within the caldera, e.g. ILO-32 (Fig. 3h). The abundance of mingled clasts at this site is $\sim-10 \%$ and the clasts range from around 5 to $20 \mathrm{~cm}$ in length.

Some decimeter-sized lithic-rich beds are observed close to the caldera edge (Fig. 3j). Medial outcrops show the same massive, lithic-rich deposits with a fine ash matrix, and lithic and juvenile pumice up to few centimetres in size (Fig. 3k). Most of the outcrops show a lower layer with higher particle concentrations. Degassing pipes are seen in this unit at some outcrops (Fig. 31). In some cases, Unit F is found directly above Unit D or with a reworked lower part (Fig. $3 \mathrm{~m}$ ).

\subsection{Unit $G$}

It is an unconsolidated, massive, well-sorted, coarse to fine ash deposit with millimeter-sized accretionary lapilli (Fig. 3n). In some outcrops, a slight stratification is observed, with a transitional contact with Unit F below. Deposits were described mainly at medial and distal outcrops (stratigraphic logs 22, 46, 49, 113, 130, 165, 169, 172, 289, 302 in Fig. 2) and found up to $100 \mathrm{~km}$ from the vent (Fig. 3o). Maximum measured thicknesses are $\sim 6 \mathrm{~m}$ (Supplementary Material 1).

\section{Physical parameters}

\subsection{Grain-size distribution}

Data from Supplementary Material 3 was plotted in Supplementary Material 4 in order to show variation of TBJ grain-size at proximal $(0-10 \mathrm{~km})$, medial $(10-40 \mathrm{~km})$ and distal locations $(>40 \mathrm{~km})$ from IC. Data include Medium Diameter (Md $\Phi)$, Sorting $(\sigma \Phi)$ and Skewness $(\alpha \Phi)$ parameters (Supplementary Material $4 \mathrm{a}-\mathrm{f}$ ) as well as $\mathrm{F} 1$ [wt\% $<1 \mathrm{~mm}$ diameter (0Ф)] and F2 [wt\% $<1 / 16 \mathrm{~mm}$ diameter (4Ф)] (Supplementary Material $4 \mathrm{~g}-\mathrm{i}$ ). Granulometric data of the local distributions characterized up to phi 10 were used to reconstruct the Total Grain Size Distributions (Fig. 4).

Figures j-ac of Supplementary Material 4 illustrate the grain-size distribution of the TBJ samples depending on distance from the caldera. Both $\mathrm{A}_{0}$ and $\mathrm{A}$ samples show a bimodal trend. Conversely, samples from Unit A are characterized by a unimodal trend. No proximal and distal samples were found for both Units $A_{0}$ and A. Only two samples from

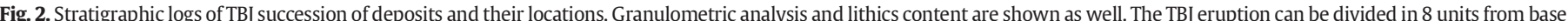

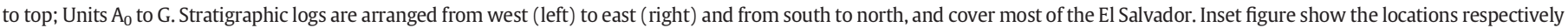
of samples and outcrops of Figs. 2 and 3. 
Unit B were collected at proximal locations, and only one of the two samples shows a unimodal trend. Medial samples from Unit B seem no show a clear relationship between distance and grain size trend similarly to the only sample from a distal outcrop that only shows a slight shift to finer classes. Two samples from Unit C at proximal locations show a polymodal trend, similarly to the ones at medial outcrops.
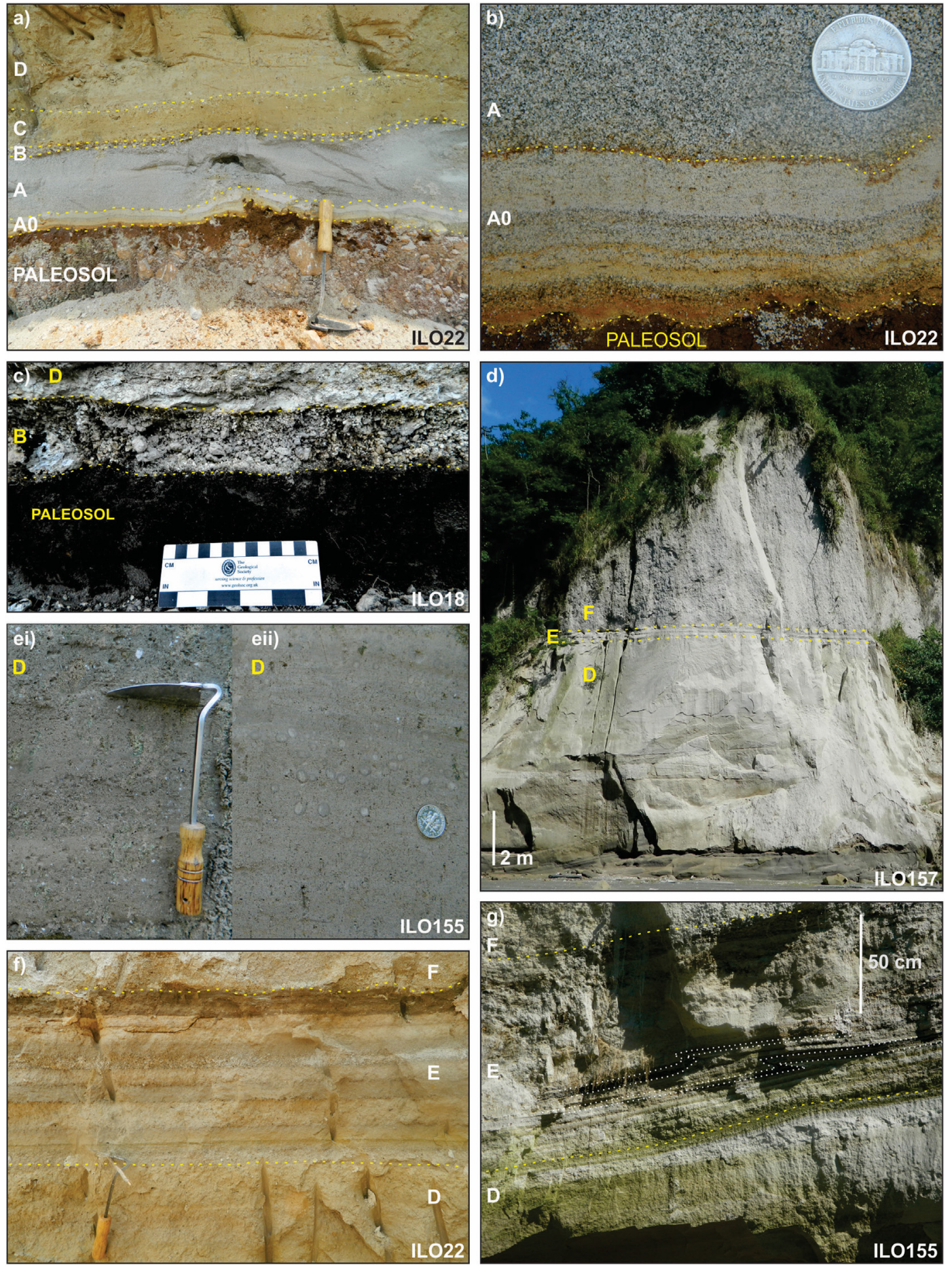

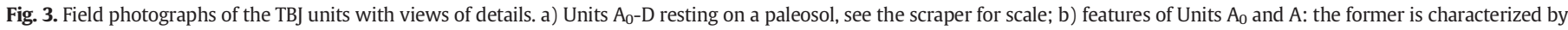

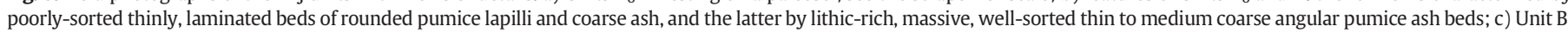

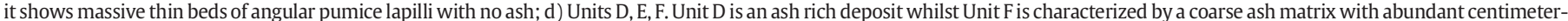

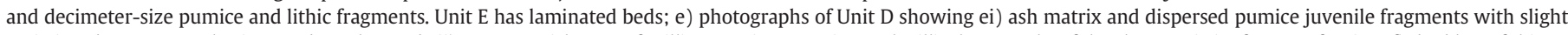

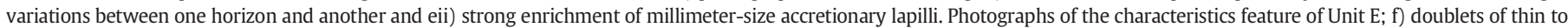

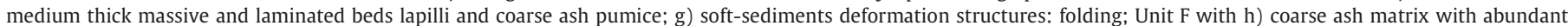

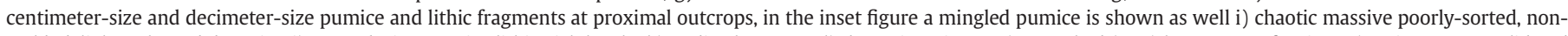

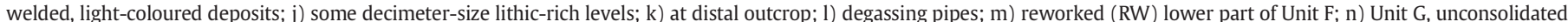

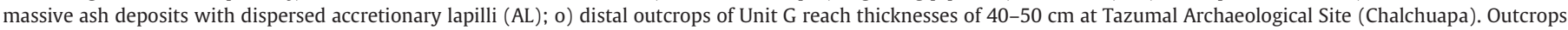

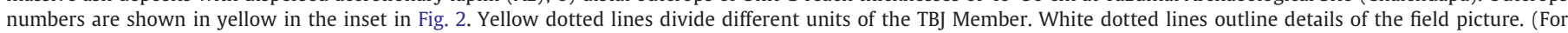
interpretation of the references to color in this figure legend, the reader is referred to the web version of this article.) 

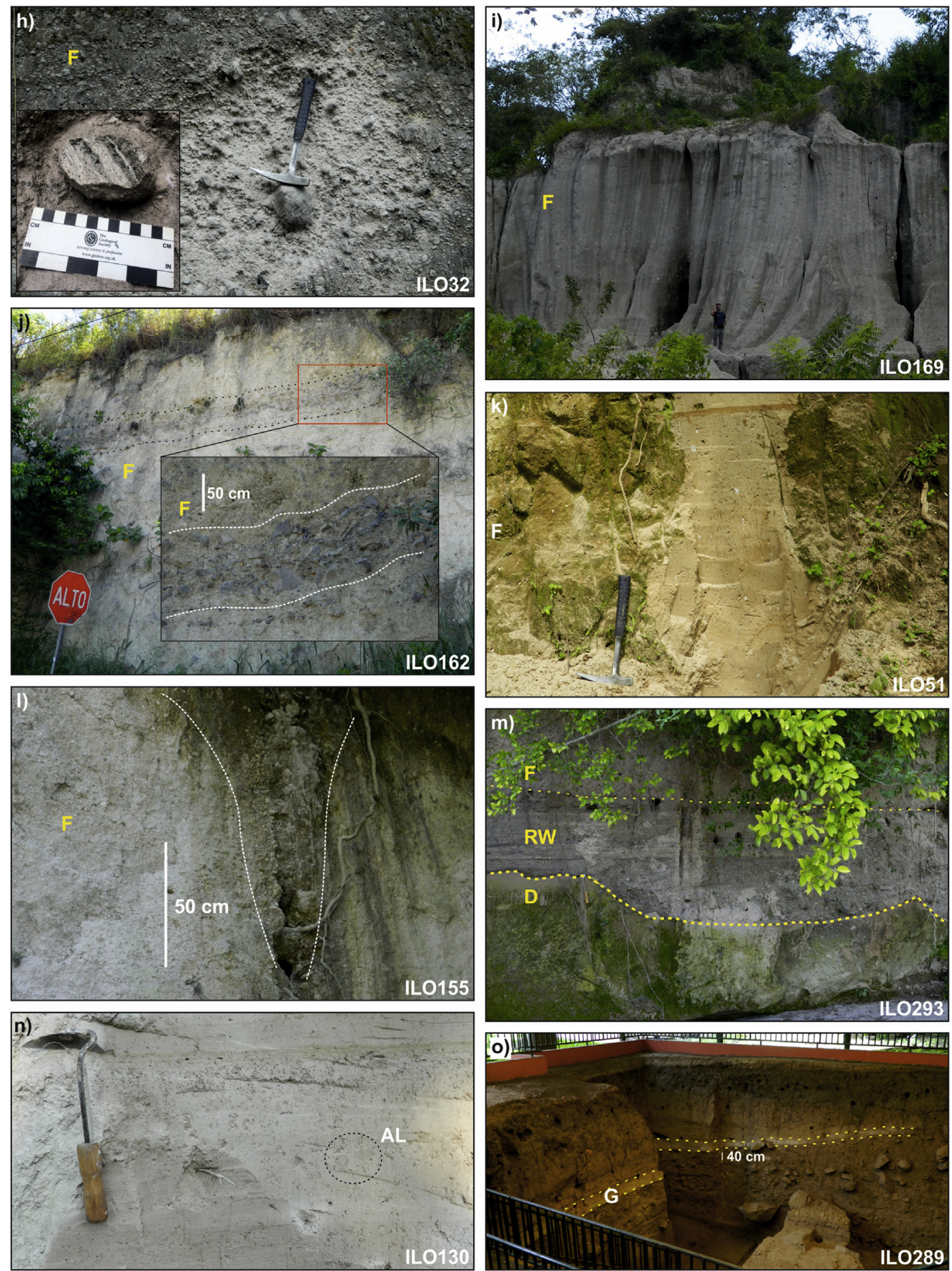

Fig. 3 (continued).

Only one sample was collected from distal outcrops showing a shift towards finer classes. However, unlike Unit C, samples from Unit D at proximal and medial outcrops have a clear polymodal trend. Therefore not a clear relationship between distance and grain size trend was observed for sample from this unit. Only one distal sample from Unit D indicates a shift towards finer classes similar to the samples from Unit C. Two proximal samples from Unit E show different tendencies with a unimodal trend but towards coarser and finer classes. The same is observed at medial distance. Only one distal outcrop from Unit E was found in the field. It shows a clear shift towards finer classes. Proximal and medial samples from Unit F show a polymodal trend with coarser classes being more representative. Distal samples from Unit F seem to show a slight bimodal trend without any substantial change in the granulometrical distribution. Only one sample from Unit $\mathrm{G}$ was collected at one proximal outcrop. Medial and distal samples from Unit G are characterized by a bimodal trend.

\subsection{Componentry analysis}

Componentry of individual beds is presented in Fig. 2 and Supplementary Material 5. The modal proportions of juvenile pumice and accidental lithic fragments (mafic clasts and pre-TBJ eruption ignimbrites) 


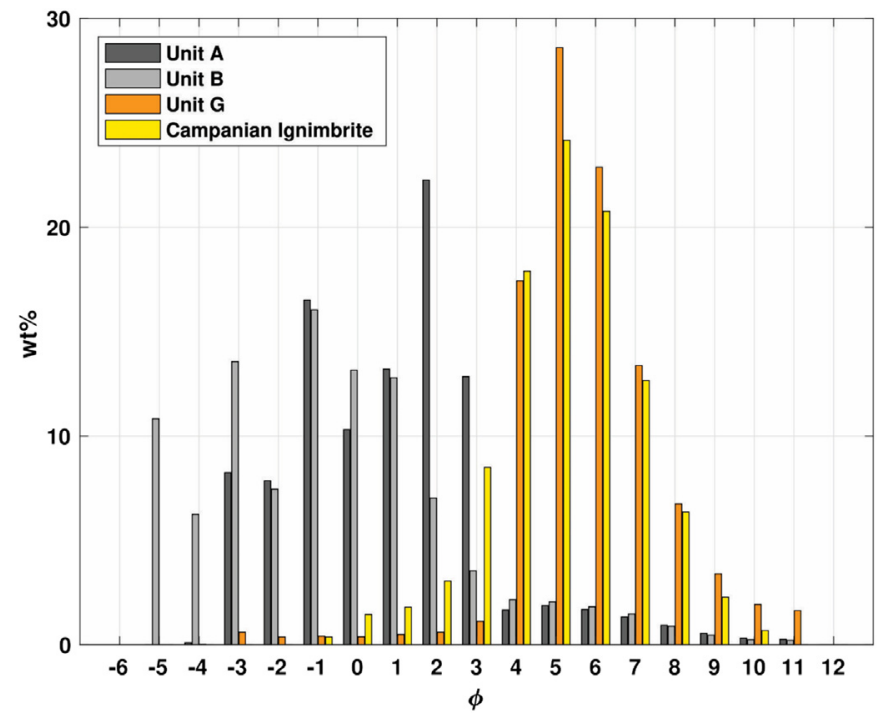

Fig. 4. Total Grain Size Distributions of fallout units (A, B and G). For the sake of comparison TGSDs associated to the co-ignimbrite phase of the Campanian Ignimbrite are also reported (Marti et al., 2016).

are given for each grain-size fraction (or class) until $2 \Phi$ and their distribution among grain-size fractions, as well as units is not constant. Unit $\mathrm{A}_{0}$, which is only present at few scattered medial outcrops, has a lithic content of $\sim 8-8.5 \%$. The following Unit A shows variable values from $\sim 10-11 \%$ up to $\sim 22-23 \%$ at medial locations. Unit B, at medial locations, shows values between $~ 15$ and $~ 19 \%$ up to $28 \%$. At distal outcrops, lithics are $\sim 12 \%$. Unit $C$ at proximal outcrops contains total lithic values of $\sim 9 \%$. Medial outcrops are characterized by lithic values of $\sim 5-8.5 \%$. Unit D shows a constant lithic content from proximal to distal outcrops with values $\sim 1-4 \%$. Unit E shows values comprised between $\sim 8 \%$ and $\sim 16 \%$ although several samples show a considerable decrease with only lithics of $\sim 3 \%$. Unit $\mathrm{F}$ at proximal outcrops shows values $~ 15 \%$ of lithics whilst at medial outcrops values are generally around $5-15 \%$. Unit $\mathrm{G}$ is characterized by lithics values at medial and distal outcrops of $\sim 1-3 \%$.

\subsection{Product distribution and volume of the different eruptive phases}

The distribution of outcrops and the thickness data (reported in the Supplementary Material 1) from each unit is shown in Fig. 5. Combining these field observations and dispersal models for each phase, we estimate the corresponding mass of erupted material (in terms of DRE) and intensity (in terms of discharge rate).

Concerning the fallout units, which includes Units A and B from sustained eruption columns, and G from a co-ignimbrite plume, we computed the tephra transport and sedimentation by solving an inverse problem (Pfeiffer et al., 2005; Costa et al., 2009) using the tephra dispersal model Hazmap (Macedonio et al., 2005). The results are summarized in Table 1, where the Total Erupted Mass (TEM), the column height, maximum wind intensity, and other physical parameters are reported for the different units. Furthermore, for Unit A we estimated a TEM of $\sim 3.5 \times 10^{11} \mathrm{~kg}$ (i.e. $0.15 \mathrm{~km}^{3}$ DRE assuming a constant magma density of $2300 \mathrm{~kg} / \mathrm{m}^{3}$ ), and an eruptive column height of $\sim 29 \mathrm{~km}$, corresponding MER of $<\sim 10^{8} \mathrm{~kg} / \mathrm{s}$ (Bonadonna and Costa, 2013). TEM for Unit $B$ is of $\sim 2 \times 10^{12} \mathrm{~kg}$ (i.e. $0.8 \mathrm{~km}^{3} \mathrm{DRE}$ ), with an eruptive column height of $\sim 7 \mathrm{~km}$, corresponding MER of $\sim 10^{5}-10^{6} \mathrm{~kg} / \mathrm{s}$ (Bonadonna and Costa, 2013). For the fallout unit $\mathrm{G}$ from the co-ignimbrite column, we adopted a first order approach similar to Matthews et al. (2012).
Results of the inverse problem for the co-ignimbrite phase suggest a TEM of $\sim 4 \times 10^{13} \mathrm{~kg}$ (i.e. $16 \mathrm{~km}^{3} \mathrm{DRE}$ ) with a co-ignimbrite plume that reached a height of $\sim 49 \mathrm{~km}$ (corresponding to a MER of $\sim 10^{10} \mathrm{~kg} / \mathrm{s}$ ). For the co-ignimbrite plume the source of ash is not "point source" but rise from all the surface of ignimbrite sheet, which can have a radius $>30-50 \mathrm{~km}$ (Costa et al., 2018). For this reason, the validity of the tephra dispersal model, which assumes virtual sources along an eruption column, is not fully appropriate for points at distances smaller than $30-50 \mathrm{~km}$ and simulation results should be considered simply as model extrapolations. However, in our case most of the available outcrops were at larger distances (see Supplementary Material 1). The individual grain-size distributions of the samples of each unit at several locations (Fig. 2 and Supplementary Material 2) were used to generate the TGSDs (Total Grain Size Distributions) reported in Fig. 4. These TGSDs were estimated using the Voronoi tessellation method of Bonadonna and Houghton (2005). For the sake of comparison, the volumes of Units A, B, and G were also assessed by adopting empirical integrations of the deposit thinning (Bonadonna and Costa, 2012).

The dispersal of the different units as isopachs is shown in Fig. 5. From these maps, we can see that Units A (Fig. 5a) and B (Fig. 5b) were mainly dispersed to the west and west-south-west areas, respectively. In contrast, Unit G (Fig. 5g) was dispersed towards the south by weak winds.

Taking into account that PDC of Unit F had a runout distance of $\sim 50 \mathrm{~km}$ (Fig. 5f), from the results of Costa et al. (2018) we can estimate a MER of order of $10^{10} \mathrm{~kg} / \mathrm{s}$, which is consistent with the value estimated for the co-ignimbrite phase (Unit G) on the basis of the height of the coignimbrite plume (see Table 1). The volume of PDC Units C, D, and F were calculated using the Delaunay triangulation method (Macedonio and Pareschi, 1991), which is, as mentioned in the Methods Section, suitable for assessing the volume between geological horizons from irregularly-spaced data points. We obtained the following volume estimations:
1. $\sim 0.7 \mathrm{~km}^{3}$ (i.e. $\sim 0.5 \mathrm{~km}^{3} \mathrm{DRE}$ ) for Unit C;
2. $\sim 5.0 \mathrm{~km}^{3}$ (i.e. $\sim 3.3 \mathrm{~km}^{3} \mathrm{DRE}$ ) for Unit D;
3. $\sim 0.5 \mathrm{~km}^{3}$ (i.e. $\sim 0.3 \mathrm{~km}^{3} \mathrm{DRE}$ ) for Unit $\mathrm{E}$;
4. $\sim 14 \mathrm{~km}^{3}$ (i.e. $\sim 9.1 \mathrm{~km}^{3} \mathrm{DRE}$ ) for Unit F.

DRE volumes were calculated using an assumed deposit density of $\sim 1500 \mathrm{~kg} / \mathrm{m}^{3}$ (Quane and Russell, 2005) and a magma density of $2300 \mathrm{~kg} / \mathrm{m}^{3}$. These volumes indicate that $30 \mathrm{~km}^{3}$ of magma was ejected during the TBJ eruption.

\section{Petrography, geochemistry and glass compositions of the TBJ deposits}

Pumice clasts from the TBJ units are moderately crystal-rich (up to $10-15 \%)$ and highly vesicular. Mineralogy assemblage consists of 70-75\% euhedral to subhedral plagioclase (andesine and labradorite; Figs. 6a-d and Fig. 7a), about 20\% of magnesio-hornblende (Figs. 6a,b, e,f and $7 \mathrm{~b}$ ), and $10 \mathrm{vol} \%$ of crystal content is made of pyroxene (Figs. 6g,h and 7c,d), Fe-Ti oxides and apatite. Plagioclase crystals often have sieve-textured cores and contain apatite inclusions, Fe-Ti oxides and clinopyroxene (Fig. 6a-d). The hornblende crystals (Fig. 6e, f) have pristine rims with abundant inclusions of apatite (Fig. 6a) and orthopyroxene.

Whole-rock compositions of the TBJ pumices are dacitic to rhyolitic (Fig. 8a and Table 2), and glass compositions are typically rhyolitic with the exception of mingled pumices found in the upper sequence (Unit F; see above) that extend to basalt (Fig. 8a). The glass compositions were determined for individual shards using an electron 

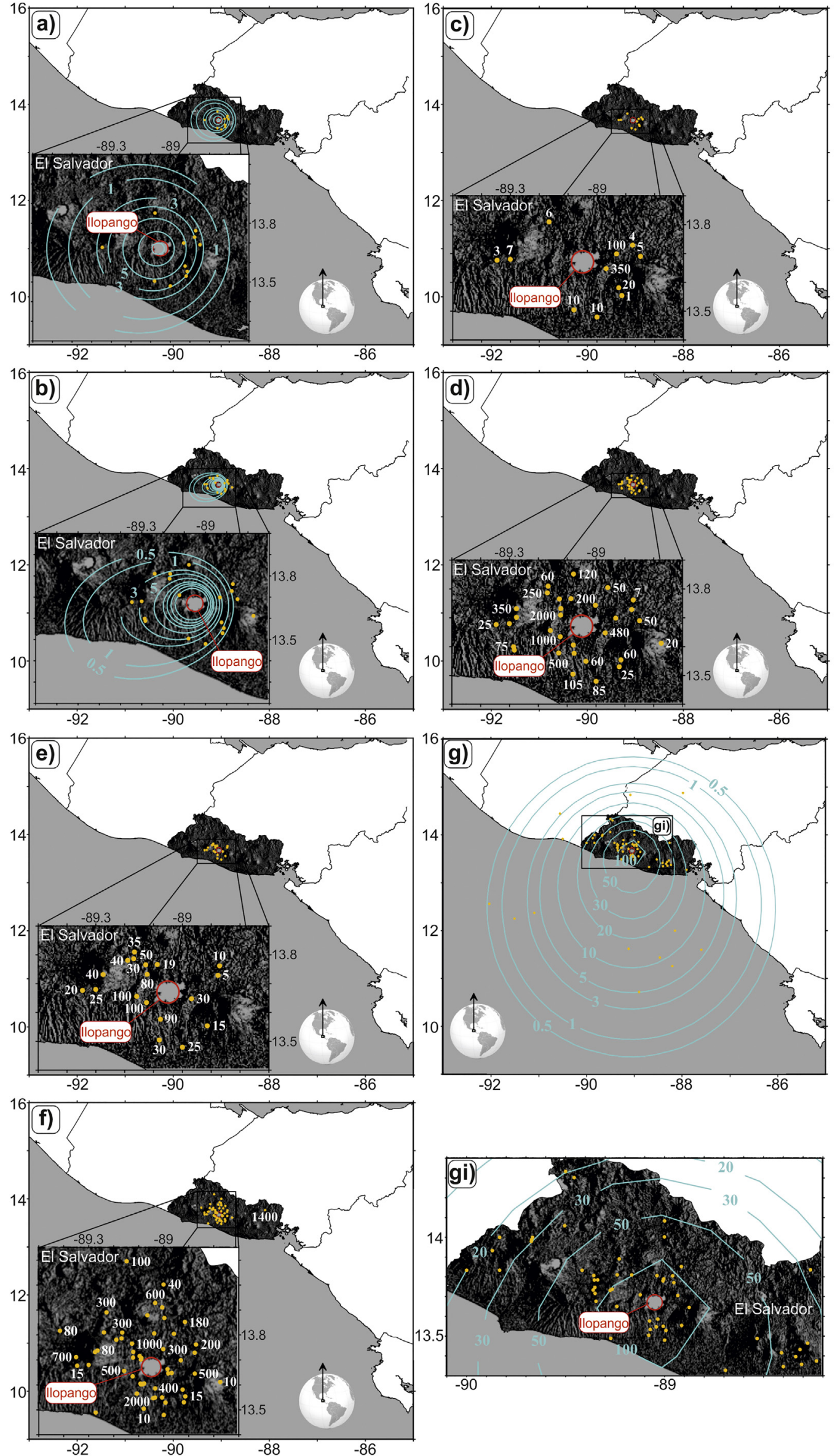

Please cite this article as: D. Pedrazzi, I. Sunye-Puchol, G. Aguirre-Díaz, et al., The Ilopango Tierra Blanca Joven (TBJ) eruption, El Salvador: Volcanostratigraphy and physical char..., Journal of Volcanology and Geothermal Research, https://doi.org/10.1016/j.jvolgeores.2019.03.006 
Table 1

Summary of the physical parameters of the deposits from the TBJ eruption.

\begin{tabular}{|c|c|c|c|c|c|c|c|c|c|c|}
\hline Physical parameters & Unit A0 & Unit A & Unit B & Unit C & Unit D & Unit E & Unit $F$ & Unit G & Total TBJ & \\
\hline Bulk Volume $\left(\mathbf{k m}^{3}\right)$ & $<0.1$ & 0.35 & 1.84 & 0.7 & 5 & 0.5 & 14 & 36.80 & 69.35 & "+ caldera filling" \\
\hline Total Erupted Mass (kg) & $<0.1$ & $3.5 \times 10^{11}$ & $2 \times 10^{12}$ & $1.2 \times 10^{12}$ & $8.2 \times 10^{12}$ & $0.7 \times 10^{12}$ & $2.3 \times 10^{13}$ & $4 \times 10^{13}$ & $7.5 \times 10^{13}$ & "+ caldera filling" \\
\hline DRE volume $\left(\mathrm{km}^{3}\right)$ & $<0.1$ & 0.15 & 0.8 & 0.5 & 3.3 & 0.3 & 9.1 & 16 & 30 & "+ caldera filling" \\
\hline Mass Eruption Rate (kg/s) & $\sim 10^{9}$ & $\sim 10^{8}$ & $\sim 10^{5}-10^{6}$ & $\sim 10^{9}$ & $\sim 10^{9}$ & $\sim 10^{9}$ & $\sim 10^{10}$ & $\sim 10^{10}$ & - & \\
\hline Runout PDC (km) & 20 & - & - & 25 & 25 & 20 & 50 & - & - & \\
\hline Column Height (km) & - & 29 & 7 & - & - & - & - & 49 & - & \\
\hline Magnitude & - & - & - & - & - & - & - & - & 6.8 & \\
\hline
\end{tabular}

microprobe from samples through the entire succession of deposits, and from both proximal and distal sites. Excluding the rare mingled clasts in Unit $\mathrm{F}$, other deposits display homogenous, rhyolitic major element compositions with $\mathrm{SiO}_{2}=75.3-78.1 \mathrm{wt} \%, \mathrm{Al}_{2} \mathrm{O}_{3}=11.9-13.8 \mathrm{wt} \%$, Total FeO $=0.99-1.53 \mathrm{wt} \%, \mathrm{MgO}=0.12-0.33 \mathrm{wt} \%, \mathrm{CaO}=0.9-1.6 \mathrm{wt}$ $\%, \mathrm{NaO}_{2}=3.78-4.88 \mathrm{wt} \%$ and $\mathrm{K}_{2} \mathrm{O}=2.38-3.37 \mathrm{wt} \%(n=239$; Table 3; Fig. 8a-d). The darkest material within the mingled pumice is basaltic and ranges down to $48.63 \mathrm{wt} \% \mathrm{SiO}_{2}, 7.91 \mathrm{wt} \% \mathrm{Al}_{2} \mathrm{O}_{3}, 12.42 \mathrm{wt}$ \% Total FeO, 12.03 wt\% MgO, and 15.02 wt\% CaO (Table 3; Fig. 8a-d). These grey bands are heterogenous in composition and extend from the least evolved composition to $\mathrm{SiO}_{2}$ concentrations up to $68.5 \mathrm{wt} \%$. The whole-rock XRF data plot between this dacitic composition and the dominant rhyolite (Fig. 8a-d).

\section{Discussion}

The volume of material erupted during the TBJ eruption was $\sim 58 \mathrm{~km}^{3}$ of bulk rock, equivalent to $\sim 30 \mathrm{~km}^{3}$ DRE of magma and corresponding to a magnitude of 6.8 (Pyle, 2000) (Table 1). Eight units can be identified in the deposits that provide evidence for distinct eruptive styles. The sedimentological and lithological characteristics of these deposits suggest that the TBJ eruption included phases associated with pure magmatic activity and those characterized by magma-water interaction, which are also seen in older intra-caldera deposits (Mann et al., 2004; Suñe-Puchol et al., 2019a, 2019b). Paleosols separate the TBJ from previous eruption deposits at several outcrops (Fig. 2). The repose period before the TBJ was of a sufficient length for this pedogenesis to occur, and the caldera was probably quiescent for around $8 \mathrm{ka}$, i.e. since TB2 (Kutterolf et al., 2008a, 2008b).

Unit $\mathrm{A}_{0}\left(<0.1 \mathrm{~km}^{3}\right.$ total DRE volume - Table 1$)$ represents the onset of the TBJ eruption. The field characteristics (Fig. 3a,b) and granulometric analysis (poorly sorted deposit, positive grain-size skewness values and a bimodal trend; Supplementary material $4 \mathrm{~b}$, e, j) suggest that this unit was deposited by dilute PDCs (Branney and Kokelaar, 2002; Dellino et al., 2004a, 2004b; Brand and White, 2007; Brand and Clarke, 2009). The high proportion of mafic lithic fragments is consistent with explosive excavation of the conduit and vent (Fig. 9a), as described in other studies e.g. Vesuvius, Italy (Barberi et al., 1989) and the AD1630 eruption of Furnas volcano, San Miguel, Azores (Cole et al., 1995). These surge clouds had a high momentum as they travelled at least up to $15-20 \mathrm{~km}$ from the vent. The deposits show similar field characteristics to the ones of the Layer LM1 from the Lower Member of the Neapolitan Yellow Tuff that represented the onset of the eruption (Orsi et al., 1992). Grain size and componentry (fine-grained deposits; Supplementary Material $4 \mathrm{~h}$ and high mafic lithic content - Fig. 2), as well as ash deposits suggest that there was magmawater interaction (Self and Sparks, 1978; Barberi et al., 1989; Houghton and Schmincke, 1989; Houghton and Smith, 1993; Cole et al., 1995;
Dellino and La Volpe, 1995; De Rita et al., 2002). The opening phases of volcanic eruptions present favourable conditions for magma-water interaction, similar to other case studies such as the Minoan, Santorini Island, Greece, AD79 Vesuvius, Italy (Cioni et al., 2000), Etna 122 BCE, Italy (Coltelli et al., 1998), and Tarawera AD1886, New Zealand (Houghton et al., 2004) eruptions.

The explosive eruptions that formed Unit A (Fig. 9b) produced an eruptive column that rose to $29 \mathrm{~km}$ (Table 1 ) and it spread mainly westwards in the proximal and medial area. Field evidence (Fig. 3a,b) and granulometric data (well-sorted deposit and a unimodal trend; Supplementary material $4 \mathrm{~b}$, e and $\mathrm{k}$ ) of samples are consistent with a tephra fallout deposit $\left(0.15 \mathrm{~km}^{3}\right.$ total DRE volume - Table 1$)$. Unit A was most likely hydromagmatic, due to the high lithic content (Fig. 2) and fine grain size at medial locations (Supplementary Material 4h) and a distribution mainly to the south of the caldera (Fig. 5a). Passing from dilute PDCs of Unit $A_{0}$ to fallout deposits of Unit $A$ is probably related to changes in magma-water mass ratio, which has been observed at several historical hydromagmatic eruptions, e.g. Kilauea volcano, Hawaii, AD1790 (McPhie et al., 1990) or Capelinhos (1957-1958) in Faial, Azores (Cole et al., 2001).

Concerning the first two phases $\left(A_{0}\right.$ and $\left.A\right)$, the magma-water mass ratio promoted a more or less high explosive efficiency, from wet PDCs and fallout deposits towards drier lapilli fall (Unit B), so the magmatic fragmentation became progressively more dominant. Then, the eruption entered a magmatic fall-dominated phase (Fig. 9c) that formed Unit B (Fig. 3c), which is characterized by highly vesiculated juvenile products released through a $\sim 7-\mathrm{km}$-high column (Table 1 ) with a grain-supported deposit mainly oriented southwestwards from the source (Fig. 5b). This eruption phase produced a coarse, generally medium sorted (Supplementary Material 4a,b,d,e), pumice fall deposit with a $0.22 \mathrm{~km}^{3}$ total DRE volume (Table 1 ). General drier conditions can be related to any factors such as, for example, the variations in magma flux or availability of water in the system, or in some cases, some batches of magma can reach the surface without explosive interaction with water, similarly to maar-diatreme eruptions (Valentine and White, 2012). Similar activity was observed for the C11 deposits of Caldeira Volcano, Faial Island, Azores (Pimentel et al., 2015). The eruption was characterized at the beginning by a series of hydromagmatic eruptions with fallout and PDCs deposits and a subsequent more dominant magmatic fragmentation, due to the rapid draining of magma from the conduit, with the establishment of a subPlinian column. The increase in the dispersal area and grain size features in the deposits (Supplementary Material 4g, h, i, l, m, n) indicates steady growth of the eruption column. The column reached its climax without major fluctuations, as there are internal bedding features and the deposits lack normal or inverse grading. This was probably facilitated by the gradual stabilization of the conduit walls associated with increasing vent diameter and magma discharge rate. 

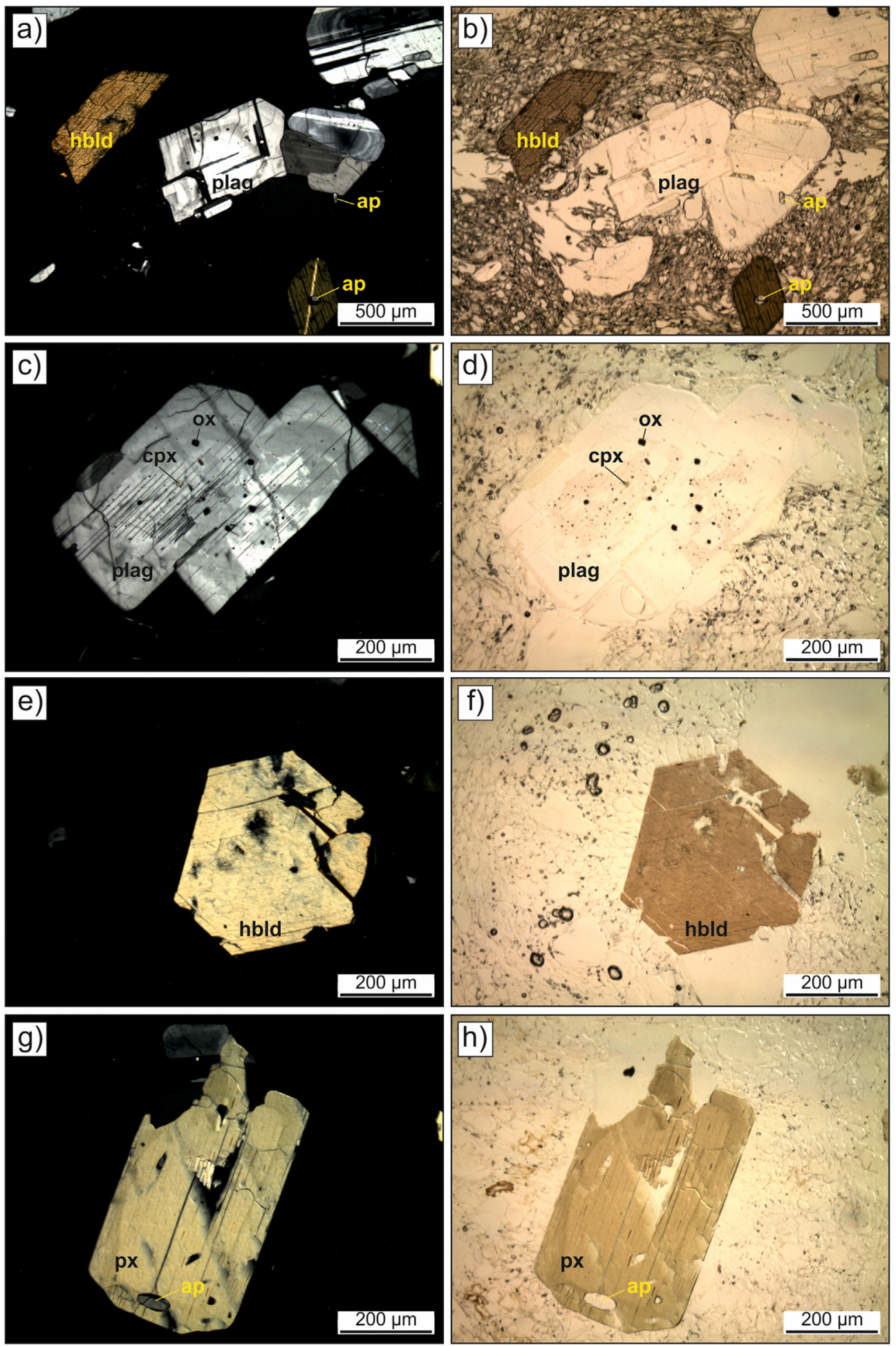

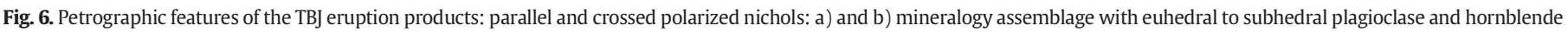

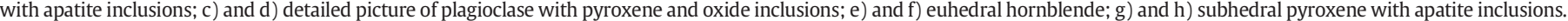

Unit C $\left(0.5 \mathrm{~km}^{3}\right.$ total DRE volume - Table 1$)$ represents an abrupt change in the eruption dynamics (Fig. 9d). This well-sorted (Supplementary Material 4a-c), massive, lithic-poor and ash-rich deposit (Supplementary Material 4d-f and $g-i)$, with few dispersed pumice fragments and accretionary lapilli indicate deposition from PDCs (Fig. 3a) that flowed mainly to the south-east part of the IC (Fig. 5c). These dynamics were probably due to the shift of the vent location and a subsequent interaction of magma with external water that led to an enhanced magma fragmentation, as well as a greater explosivity of the eruption that contributed to the generation of fine ash (Supplementary Material 4o-q). The stratigraphic position of these hydromagmatic deposits immediately above the magmatic deposits suggests a subsequent access of the lake water to the column of rising magma. However, we cannot discount the role of hydrothermal and groundwater in the hydromagmatic episode that lead to the emplacement of Unit $C$. The presence of 


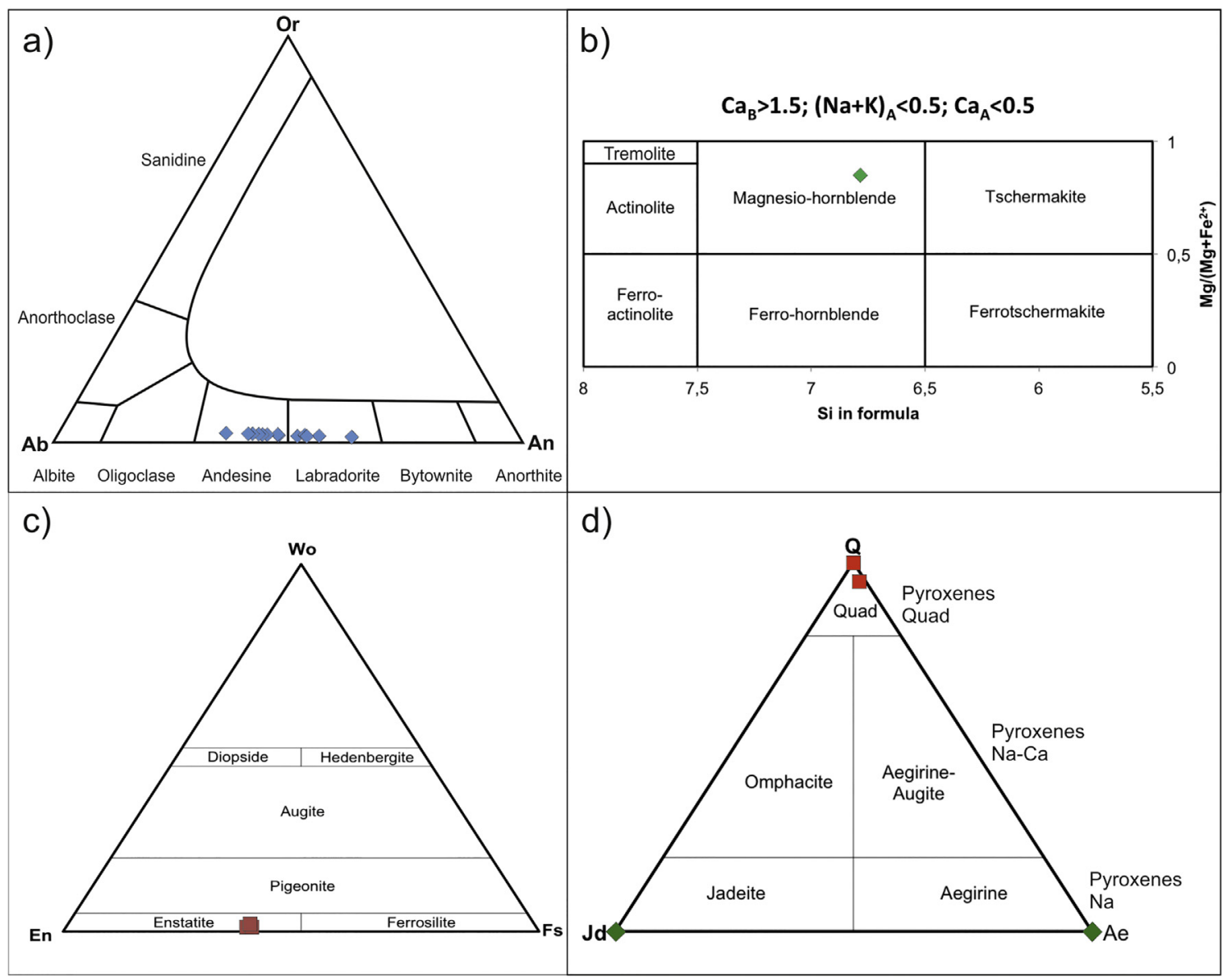

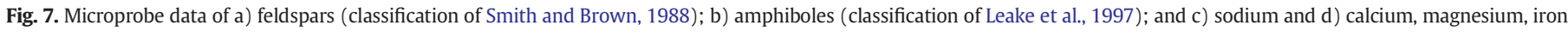
pyroxenes (classification of Morimoto, 1989) diagrams.

hydrothermally altered lithic fragments suggests the occurrence of an extensive hydrothermal system within the caldera at the time of the eruption (Saxby et al., 2016).

Unit D ( $3.3 \mathrm{~km}^{3}$ total DRE volume - Table 1 ) shows similar field characteristics (Fig. 3d,e) and granulometric data (Supplementary Material $4 \mathrm{a}-\mathrm{C}$ and $\mathrm{r}-\mathrm{t}$ ) to the previous unit $\mathrm{C}$ (Fig. 3d), and suggest it was emplaced from PDCs of hydromagmatic origin (Fig. 9d). The hydrothermally altered lithic fragments observed in Unit $C$ are not recognized in the Unit D, so the ongoing magma-water interaction was most likely fuelled by surface water. A shallow lake seems to have been present in the IC at $\geq 43.670$ ka years ago as proposed by Mann et al. (2004) although the last study of Suñe-Puchol et al. (2009a) suggests the presence of a paleolake already at $1.5 \mathrm{Ma}$. As proposed by Aravena et al. (2018), natural aquifers appear unlikely to be sources of enough water to significantly affect the eruptive dynamics of an event with high mass discharge rate; conversely, evidence for magma-water interaction are probably related to the involvement of surface water or the injection of groundwater by high-magnitude collapse mechanisms. The same type of activity was also reported for Taal caldera lake, Philippines in 1991 (Delmelle and Bernard, 2000), the hydromagmatic eruption of Kilauea Volcano, Hawaii, in 1970 (Mastin, 1997), or the Nari Caldera at Ulleung Island, Korea (Kim et al., 2014). Changes from dry to wet conditions in such eruptions were also observed for the Askja 1875 eruption, Iceland (Sparks et al., 1981; Carey et al., 2010) and the AD232 Taupo eruption, New Zealand (Houghton et al., 2000). The absence of any fall deposits at the base of Units C and D rules out the possibility of a sustained eruptive column phase (Fig. 5d).

During the course of the eruption, there was another change in the eruptive dynamics, with a switch to drier conditions (Fig. 9e). Unit E
( $0.3 \mathrm{~km}^{3}$ total DRE volume - Table 1$)$ was deposited by alternation of dilute PDCs and fallout, which is based on plane-parallel and low-angle cross laminations and grain-supported layers without traction structures (Fig. 3f; Chough and Sohn, 1990; De Rosa et al., 1992; Dellino et al., 2004b; Solgevik et al., 2007), alternation of well and poorly sorted deposits (Supplementary Material $4 \mathrm{a}-\mathrm{c}$ ) of ash and lapilli (Supplementary Material $4 \mathrm{~g}-\mathrm{i}$ ), and a clear polymodal trend of the grain size distribution (Supplementary Material $4 \mathrm{u}-\mathrm{w}$ ). Soft sediment folding (Fig. $3 g$ ) might indicate that some of the layers were deposited wet as consequence of magma-water interaction, thus characterizing the whole unit as alternation of dry and wet deposits that were deposited around the IC (Fig. 5e). At this time, due to structural faults that characterize IC, the magma might have had interaction with the almost empty Ilopango Lake after Unit D phase, thus allowing an intermittent magma-water interaction with the formation of short-lived columns and lateral blast.

It is important to consider how, not only a change in the watermagma ratio might have led to the emplacement of fallout and PDCs deposits, but also the scaled depth (ratio between depth of explosion and energy) can have huge effects on deposit characteristics, grain size and deposit morphology (see Taddeucci et al., 2013; Graettinger et al., 2014, 2015; Valentine et al., 2014, 2015; Sonder et al., 2015). As suggested in Graettinger et al. (2015), when scaled depth is constant, the crater focuses the jet and results in decreasing overall volumes of coarse ejecta and the potential occurrence of fine-grained dilute density current deposits. Progressively increasing scaled depth results in an overall decrease in ejecta volume to the point where the explosion is confined and no ejecta are produced. A progressive decrease in scaled depth will result in an increase in ejecta volume and in the grain size of ejecta 

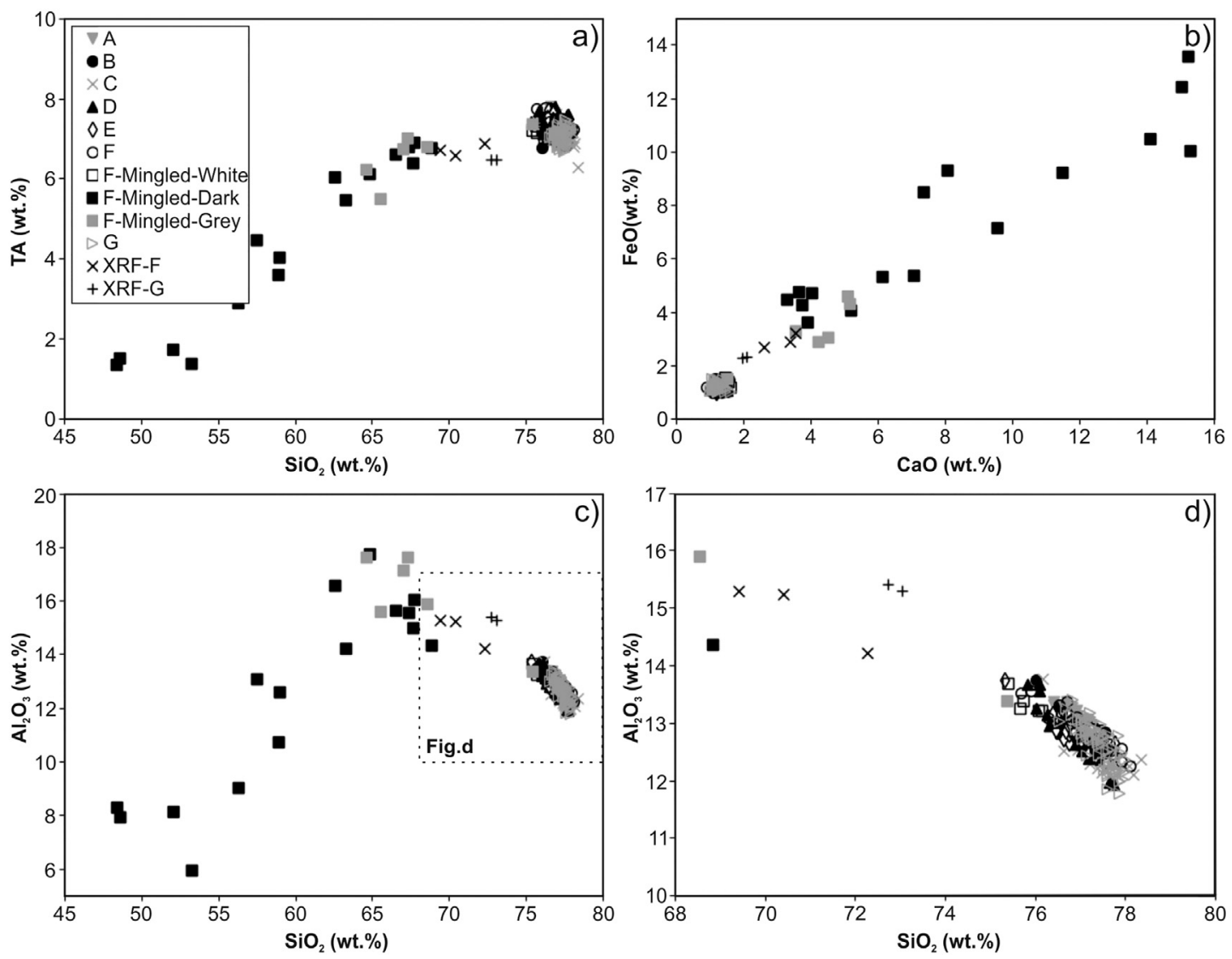

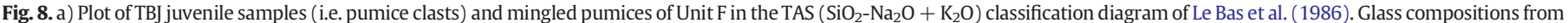

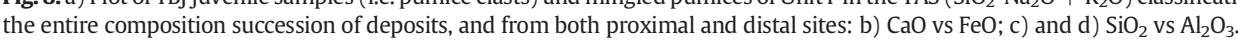

deposits and low occurrence of fine-grained dilute density currents as the jet is larger than the previous crater and therefore does not exhibit significant focusing.

The final phase (Fig. 9f) of the eruption was marked by a dramatic change in eruptive style with deposition of chaotic, massive, poorlysorted (Supplementary Material 4a-c), non-welded dry thick PDC deposits (Fig. 3h, i). The lag-breccia deposits of Unit F are observed only close to the caldera topographic edge (Fig. 3j). This might be related to the strong control exerted by the paleotopography on facies architecture as observed, for example, for the Abrigo Ignimbrite in Tenerife, Canary Islands (Pittari et al., 2006) or the Acatlán ignimbrite, Mexico (Branney and Kokelaar, 1997). This is a lithic-rich ignimbrite that represents continued clearing from fissure vents along the main bounding caldera faults (Fig. 9f). The sharp, erosive lower contact with underlying units, coarse, up to meter-sized lithic clasts and juveniles in a poorly sorted matrix (Fig. 3h-k), together with granulometric analyses (Supplementary Material $4 \mathrm{~g}-\mathrm{i}$ and $\mathrm{x}-\mathrm{z}$ ), suggest eruptive dynamics that were dominated by vigorous and prolonged pyroclastic fountaining that produced sustained quasi-steady PDCs, as the eruption waxed and stabilized. Both basal high-particle concentrations in the PDCs and the long runout distances were maintained because of the continuous supply of dense currents at the vent (Roche et al., 2016). These deposits formed an ignimbrite sheet, Unit F ( $9.3 \mathrm{~km}^{3}$ total DRE volume-Table 1) that reached the sea on southern sectors of the caldera and was widespread around IC (Fig. 5f). At this point, the increase in the magma eruption rate could have been produced by the start of the caldera collapse, which would have commenced the rapid evacuation of magma from the sub-caldera magma chamber, leading to a subsequent inefficient magma-water interaction during F eruptive phase. Similar mechanisms from wet to drier conditions were also observed during the Neapolitan
Yellow Tuff eruption (Orsi et al., 1992). The mingled pumice clasts that extend to basaltic compositions are also found in deposits from this phase of the eruption suggesting that additional melts were erupted. Since these distinctive less evolved compositions are restricted to the clasts in the very proximal outcrops it implies that the erupted volume of this melt was incredibly small. It is quite common for additional melts to be erupted during caldera formation (cf. Smith et al., 2016).

As for Units C and D, no fallout layers were recognized at the base of Unit F, thus, suggesting that an initial buoyant Plinian eruption columnbuilding phase was not produced. This feature is similar to other ignimbrites such as Campanian (Marti et al., 2016) and Ora in Italy (Willcock et al., 2013), or Huichapan in Mexico (Pacheco-Hoyos et al., 2018). The occurrence of fines-poor elutriation pipes (Fig. 31) indicates that following deposition, vigorous gas escape occurred elutriating fines. These pipes are interpreted as evidence of rapid emplacement involving particle segregation and vigorous, post emplacement fluid (dusty gas) escape (Branney and Kokelaar, 2002), thus suggesting that at the time of deposition Unit $\mathrm{F}$ deposits were hot.

Unit G (Fig. 3n) represents the final co-ignimbritic deposit of the TBJ eruption (Fig. 9g). Deposits were found at medial and distal locations that are $>100 \mathrm{~km}$ from the caldera (Fig. 30). This unit is made of moderately to poorly sorted (Supplementary Material $4 a-c$ ) ash (Supplementary Material 4g-i) with a clear bimodality grain-size distribution trend (Supplementary Material 4aa-ac) that highlights the significance of ash aggregation processes in the transport and deposition.

The absence of Plinian pumice fall deposits preceding the dense PDC deposits of TBJ is a typical characteristic of graben-type calderas as Ilopango (Aguirre-Díaz and Martí, 2015; Aguirre-Díaz et al., 2016, 2017; Saxby et al., 2016; Suñe-Puchol et al., 2019a) or fissure ignimbrite eruptions related to local/regional faults (Aguirre-Díaz and Labarthe- 
Table 2

Whole rock analyses of representative TBJ samples.

\begin{tabular}{|c|c|c|c|c|c|}
\hline Sample & ILO-32-2 & ILO-128-1 & ILO-169-A & ILO-302-1 & ILO-303-1 \\
\hline TBJ Unit & $\mathrm{F}$ (base) & $\mathrm{F}$ (base) & $\mathrm{F}$ (base) & & G \\
\hline Site & Apulo & S. Anton. Masahuat & Oratorio & La Union & Santa Elena \\
\hline Distance & Proximal & Medial & Medial & Distal & Distal \\
\hline Latitude & $\mathrm{N} 13^{\circ} 42.504^{\prime}$ & $\mathrm{N} 13^{\circ} 32.826^{\prime}$ & $\mathrm{N} 13^{\circ} 48.382^{\prime}$ & $\mathrm{N} 13^{\circ} 16.263^{\prime}$ & $\mathrm{N} 13^{\circ} 24.965^{\prime}$ \\
\hline Longitude & W89 $05.365^{\prime}$ & W89 $02.510^{\prime}$ & W8902.301' & $W 87^{\circ} 54.421^{\prime}$ & W88 $24.560^{\prime}$ \\
\hline \multicolumn{6}{|c|}{ Major and minor elements (oxides, wt.\%) } \\
\hline $\mathrm{SiO}_{2}$ & 67.34 & 70.325 & 68.631 & 70.45 & 70.081 \\
\hline $\mathrm{TiO}_{2}$ & 0.408 & 0.301 & 0.34 & 0.247 & 0.25 \\
\hline $\mathrm{Al}_{2} \mathrm{O}_{3}$ & 14.833 & 13.826 & 14.846 & 14.744 & 14.835 \\
\hline $\mathrm{Fe}_{2} \mathrm{O}_{3}$ & 3.475 & 2.913 & 3.142 & 2.431 & 2.495 \\
\hline $\mathrm{MnO}$ & 0.122 & 0.109 & 0.113 & 0.099 & 0.101 \\
\hline $\mathrm{MgO}$ & 1.216 & 0.873 & 0.995 & 0.557 & 0.597 \\
\hline $\mathrm{CaO}$ & 3.453 & 2.528 & 3.311 & 1.9 & 2.01 \\
\hline $\mathrm{Na}_{2} \mathrm{O}$ & 4.317 & 4.263 & 4.295 & 3.623 & 3.64 \\
\hline $\mathrm{K}_{2} \mathrm{O}$ & 2.188 & 2.433 & 2.122 & 2.621 & 2.595 \\
\hline $\mathrm{P}_{2} \mathrm{O}_{5}$ & 0.133 & 0.097 & 0.105 & 0.06 & 0.067 \\
\hline Total & 99.975 & 99.888 & 99.99 & 99.932 & 99.891 \\
\hline LOI & 2.49 & 2.22 & 2.09 & 3.2 & 3.22 \\
\hline \multicolumn{6}{|c|}{ Trace elements (ppm) } \\
\hline $\mathrm{Li}$ & 14 & 15 & 8 & 20 & 20 \\
\hline $\mathrm{Be}$ & 1 & 1 & 1 & 1 & 1 \\
\hline B & 43 & 73 & 41 & 39 & 31 \\
\hline $\mathrm{P}$ & 0 & 0 & 0 & 0 & 0 \\
\hline Sc & 5 & 3 & 7 & 2 & 3 \\
\hline $\mathrm{Ti}$ & 0 & 0 & 0 & 0 & 0 \\
\hline V & 40 & 27 & 34 & 20 & 22 \\
\hline $\mathrm{Cr}$ & 3 & 3 & 3 & 3 & 3 \\
\hline Co & 5 & 4 & 4 & 3 & 4 \\
\hline $\mathrm{Ni}$ & 2 & 2 & 3 & 2 & 2 \\
\hline $\mathrm{Cu}$ & 9 & 6 & 8 & 14 & 16 \\
\hline $\mathrm{Zn}$ & 47 & 44 & 44 & 40 & 41 \\
\hline $\mathrm{Ga}$ & 14 & 13 & 13 & 14 & 14 \\
\hline $\mathrm{Rb}$ & 37 & 48 & 27 & 56 & 55 \\
\hline $\mathrm{Sr}$ & 308 & 242 & 284 & 191 & 213 \\
\hline Y & 17 & 17 & 15 & 17 & 17 \\
\hline $\mathrm{Zr}$ & 144 & 149 & 149 & 139 & 143 \\
\hline $\mathrm{Nb}$ & 3 & 4 & 3 & 4 & 4 \\
\hline Mo & 2 & 2 & 2 & 2 & 2 \\
\hline Sn & 1 & 1 & 1 & 3 & 3 \\
\hline $\mathrm{Sb}$ & 1 & 1 & 1 & 1 & 1 \\
\hline Cs & 2 & 2 & 2 & 3 & 3 \\
\hline $\mathrm{Ba}$ & 997 & 1111 & 974 & 1271 & 1199 \\
\hline La & 12 & 13 & 10 & 14 & 13 \\
\hline $\mathrm{Ce}$ & 24 & 26 & 19 & 28 & 28 \\
\hline $\mathrm{Pr}$ & 3 & 3 & 3 & 3 & 3 \\
\hline $\mathrm{Nd}$ & 13 & 13 & 11 & 13 & 13 \\
\hline $\mathrm{Sm}$ & 3 & 3 & 2 & 3 & 3 \\
\hline $\mathrm{Eu}$ & 1 & 1 & 1 & 1 & 1 \\
\hline $\mathrm{Tb}$ & 0 & 0 & 0 & 0 & 0 \\
\hline $\mathrm{Gd}$ & 3 & 3 & 2 & 3 & 3 \\
\hline Dy & 3 & 3 & 2 & 3 & 3 \\
\hline $\mathrm{Ho}$ & 1 & 1 & 1 & 1 & 1 \\
\hline $\mathrm{Er}$ & 2 & 2 & 2 & 2 & 2 \\
\hline $\mathrm{Yb}$ & 2 & 2 & 2 & 2 & 2 \\
\hline Lu & 0 & 0 & 0 & 0 & 0 \\
\hline $\mathrm{Hf}$ & 4 & 4 & 4 & 4 & 4 \\
\hline Ta & 0 & 0 & 0 & 0 & 0 \\
\hline W & 0 & 1 & 0 & 1 & 1 \\
\hline TI & 0 & 0 & 0 & 0 & 0 \\
\hline $\mathrm{Pb}$ & 6 & 7 & 6 & 8 & 8 \\
\hline Th & 3 & 3 & 2 & 4 & 4 \\
\hline U & 1 & 2 & 1 & 2 & 2 \\
\hline
\end{tabular}

Samples analysed by X-Ray Fluorescence in the Insituto de Geología (UNAM) by Patricia Girón.

Coordinates in WGS84 system (zone 16P).

LOI: Lost of ignition.

Hernández, 2003; Aguirre-Díaz et al., 2008). This is due to the significant control of tectonic stress on mass discharge rate (Costa et al., 2011; Costa and Martí, 2016), with graben-type calderas tending to generate large MER larger that are too high to sustain a Plinian column (see Costa et al., 2018).

The TBJ deposits highlight that a single eruption can produce a complex sequence of eruption styles and depositional processes. The magnitude of this eruption means that Mayan populations living in the region would have been considerably affected (Dull et al., 2001; Hernández, 2004; Hernández et al., 2015). The human populations directly affected

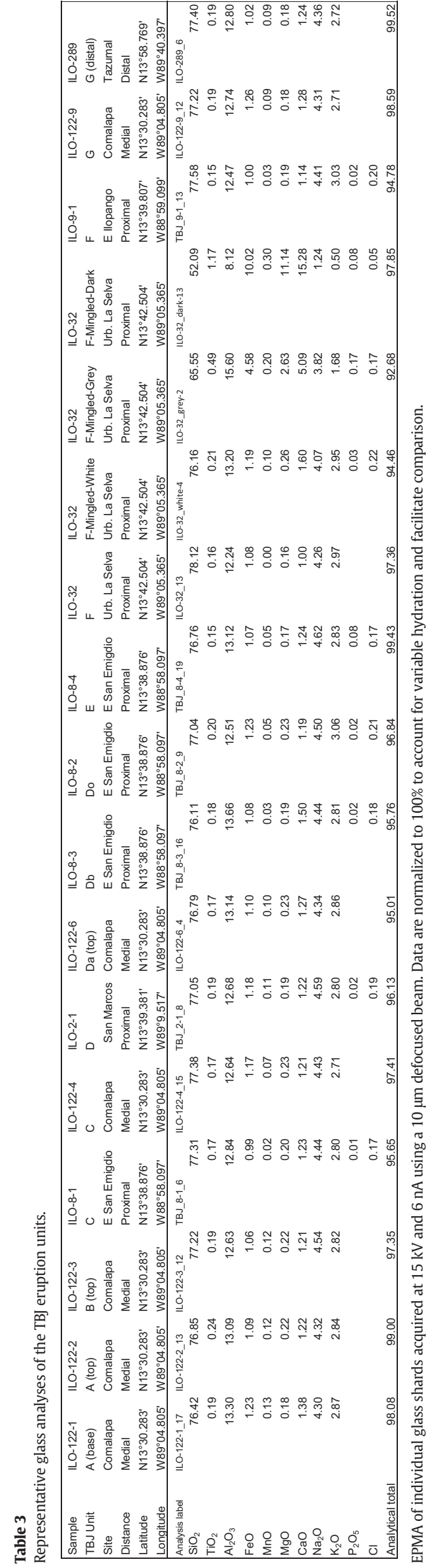



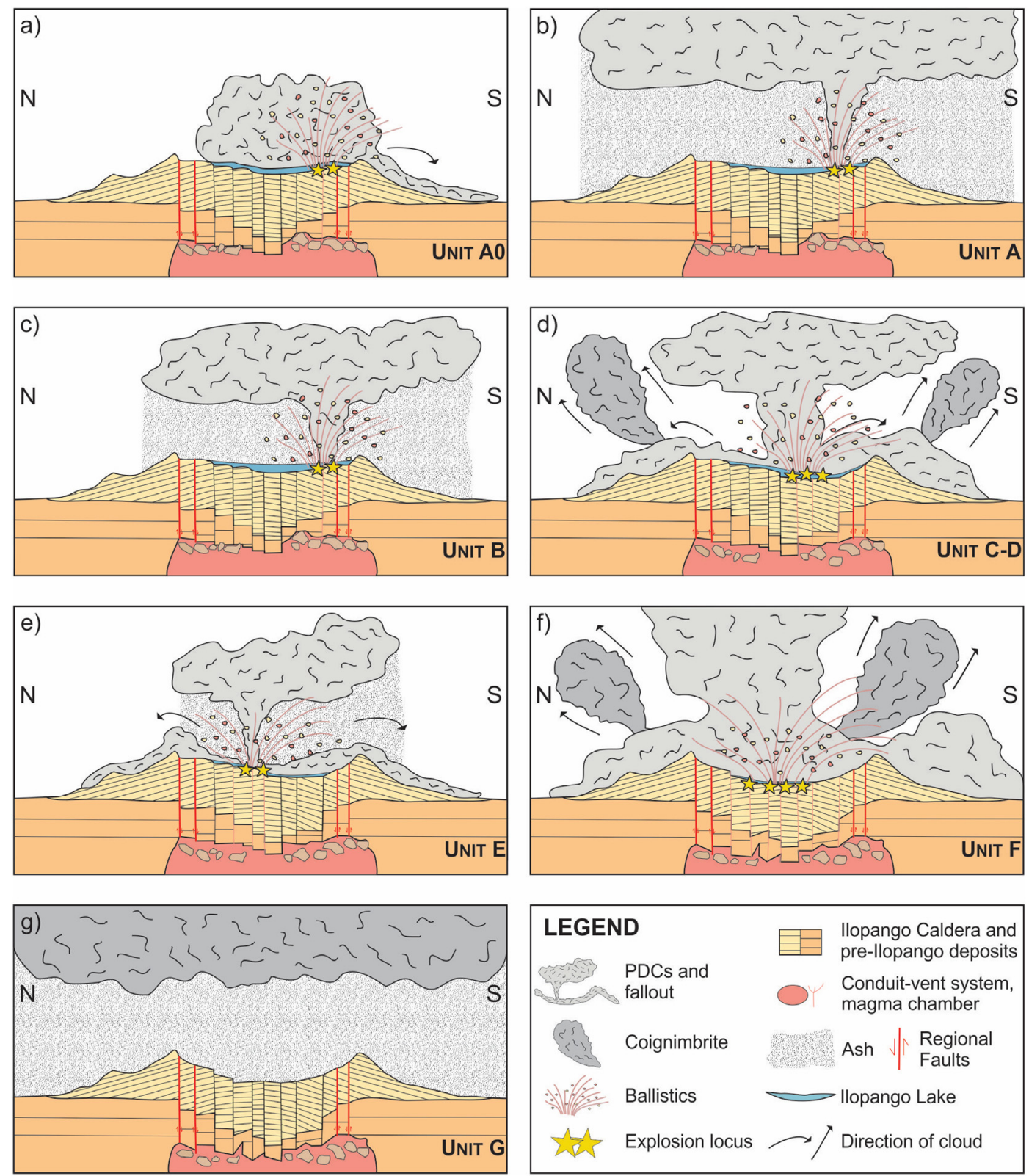

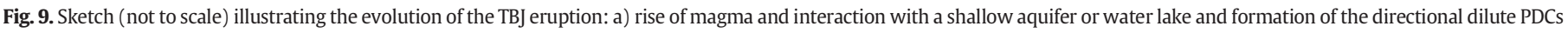

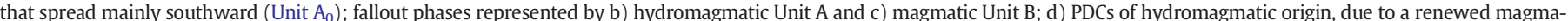

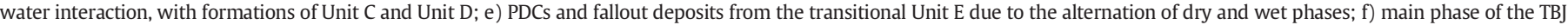
eruption with deposition of Unit F by dense PDCs associated to the caldera collapse; $g$ ) co-ignimbrite deposits.

by the TBJ eruption would have been those living in the territory within $50 \mathrm{~km}$ of the IC. However, the indirect effects on social, economic, and political systems probably affected a much wider area of Mesoamerica (Dull et al., 2001). It has also been suggested that the sulphate peak, typically associated with volcanic eruptions, in the both Greenland and Antarctic ice cores at 539-540 CE could be associated with the TBJ eruption (Sigl et al., 2015). These peaks are associated with the $\mathrm{H}_{2} \mathrm{SO}_{4}$ aerosols that are injected into the high atmosphere during large volcanic eruptions, which increase the albedo and potentially produce a volcanic winter period (Robock, 2000). However, the date of the eruption has not been sufficiently resolved to establish if these sulphate peaks in the polar ice cores are in fact associated with the TBJ eruption as the ${ }^{14} \mathrm{C}$ dates fall on a plateau in the radiocarbon calibration curve (e.g., Reimer et al., 2013), which results in an imprecise eruption range of AD270-AD400 (Lohse et al., 2018) to AD440-550 (Dull et al., 2010).
The examination of this eruption sheds light on a number of important implications for hazard assessment when considered within the framework of the volcanism associated with IC and Country of El Salvador. The detailed study of the TBJ eruption together with the ones of Suñe-Puchol et al. (2019a, 2019b) about the older eruptions of IC, represent the first and necessary step towards improved volcanic hazard assessments for the region. These are essential to mitigate volcanic risk for the large number of communities, including the City of San Salvador, that are expanding around this active volcano.

\section{Conclusion}

In this study, we conducted a detailed stratigraphic and lithological study of the dacitic pumice Tierra Blanca Joven (TBJ) deposit. The TBJ is the last explosive eruption of Ilopango Caldera, representing a singular eruptive episode and constitutes the last eruptive cycle of the Tierra 
Blanca sequence that starts with the TB4 eruption deposit. The TBJ eruption erupted $\sim 58 \mathrm{~km}^{3}$ of bulk volume rock or $\sim 30 \mathrm{~km}^{3}$ DRE of magma, corresponding to a 6.8 magnitude eruption.

The eruption was characterized by eight phases $\left(A_{0}-G\right)$ with distinct eruptive styles without major pauses in between. The eruption started with dilute PDCs followed by two fallout phases that left only few $\mathrm{cm}$ of deposits, found mainly close to the IC. Subsequently, dense and dilute PDCs of hydromagmatic and magmatic origin filled the depressions near the Ilopango Lake. Deposits thicknesses are up to $70 \mathrm{~m}$ and reached distances of at least $40 \mathrm{~km}$ from the vent, covering the area where the city of San Salvador is now located. Finally, coignimbritic ash deposits of the last stage of the eruption were found all over El Salvador with significant thicknesses, and also found dispersed into neighbouring countries.

The TBJ was a cataclysmic event and is considered to be one of the largest Quaternary eruptions in Central America. TBJ eruptive products would have considerably affected the Mayan populations living in Salvadorian and nearby territories at that time. Consequently, long- and short-term hazard assessments for IC should take into account all possible scenarios including those described for the TBJ eruption.

Supplementary data to this article can be found online at https://doi. org/10.1016/j.jvolgeores.2019.03.006.

\section{Acknowledgements}

This study was financed by CONACYT-CB grant 240447 to GJAD and logistically supported by MARN-El Salvador and PNC-El Salvador. We thank Caterina Muñoz Torres, Academic Technician of CGEO and the students Karina Rodríguez García and Katia Jasso Torres for their help during the survey. This manuscript was greatly improved by comments and suggestions from the chief-editor Joan Martí and an anonymous reviewer.

\section{References}

Aguirre-Díaz, G.J., 2008. Types of collapse calderas. Collapse Calderas Workshop 19-25 October 2008, Querétaro, Mexico "Reconstructing the Evolution of Collapse Calderas: Magma Storage, Mobilization and Eruption". IOP Conference Series: Earth Environ. Sci., 3012021 (5pp).

Aguirre-Díaz, G.J., Labarthe-Hernández, G., 2003. Fissure ignimbrites: Fissure-source origin for voluminous ignimbrites of the Sierra Madre Occidental and its relationship with Basin and Range faulting. Geology 31 (9), 773-776.

Aguirre-Díaz, G.J. and Martí, J., 2015. Graben calderas: examples from Mexico, Central America, and the Andes. 26th IUGG General Assembly, Prague, Czech Republic, June 22-July 2, 2015.

Aguirre-Díaz, G.J., Labarthe-Hernández, G., Tristán-González, M., Nieto-Obregón, J., Gutiérrez-Palomares, I., 2008. The ignimbrite flare-up and graben calderas of the Sierra Madre Occidental, Mexico. Dev. Volcanol. 10, 143-180.

Aguirre-Díaz, G.J., Suñe-Puchol, I., Dávila-Harris, P., Pedrazzi, D., Hernández, W. and Gutiérrez, E., 2016. Volcanic history of the Ilopango caldera, Central American Volcanic Arc: Cities on Volcanoes 9, IAVCEI; Puerto Varas, Chile, (November 2016).

Aguirre-Díaz, J.G., Suñe-Puchol, I., Davila-Harris, P., Pedrazzi, D., Hernandez, W. and Gutierrez, E., 2017 Volcanic history of the Ilopango caldera, Central American Volcanic Arc. 113th Annual Meeting, 2017 GSA Cordilleran Section, Hawaii, USA.

Aravena, A., Vitturi, M., Cioni, R., Neri, A., 2018. Physical constraints for effective magmawater interaction along volcanic conduits during silicic explosive eruptions. Geology 46 (10), 867-870.

Barberi, F., Cioni, R., Rosi, M., Santacroce, R., Sbrana, A., Vecci, R., 1989. Magmatic and phreatomagmatic phases in explosive eruptions of Vesuvius as deduced by grainsize and component analysis of the pyroclastic deposits. J. Volcanol. Geotherm. Res. 38 (3), 287-307.

Barckhausen, U., Ranero Cesar, R., Huene, R., Cande Steven, C., Roeser Hans, A., 2001. Revised tectonic boundaries in the Cocos Plate off Costa Rica: Implications for the segmentation of the convergent margin and for plate tectonic models. J. Geophys. Res. Solid Earth 106 (B9), 19207-19220.

Bernal, J.B., Lozano-Santacruz, R., 2005. Characterization of a new set of eight geochemical reference materials for XRF major and trace element analysis. Revista Mexicana de Ciencias Geológicas 22 (3), 329-344.

Bonadonna, C., Costa, A., 2012. Estimating the volume of tephra deposits: a new simple strategy. Geology 40 (5), 415-418.

Bonadonna, C., Costa, A., 2013. Plume height, volume, and classification of explosive volcanic eruptions based on the Weibull function. Bull. Volcanol. 75 (8), 742.

Bonadonna, C., Houghton, B.F., 2005. Total grain-size distribution and volume of tephrafall deposits. Bull. Volcanol. 67 (5), 441-456.
Brand, B.D., Clarke, A.B., 2009. The architecture, eruptive history, and evolution of the Table Rock complex, Oregon: from a Surtseyan to an energetic maar eruption. J. Volcanol. Geotherm. Res. 180 (2), 203-224.

Brand, B.D., White, C.M., 2007. Origin and stratigraphy of phreatomagmatic deposits at the Pleistocene Sinker Butte Volcano, Western Snake River Plain, Idaho. J. Volcanol. Geotherm. Res. 160 (3), 319-339.

Branney, M.J., Kokelaar, P., 1997. Giant bed from a sustained catastrophic density current flowing over topography: Acatlan ignimbrite, Mexico. Geology 25 (2), 115-118.

Branney, M.J., Kokelaar, P., 2002. Pyroclastic Density Currents and the Sedimentation of Ignimbrites (Geological Society of London).

Canora, C., Villamor, P., Martínez-Díaz, J.J., Berryman, K.R., Álvarez-Gómez, J.A., Capote, R., Hernández, W., 2012. Paleoseismic analysis of the San Vicente segment of the El Salvador Fault Zone, EL Salvador, Central America. Geol. Acta 10, 103-123.

Carey, R.J., Houghton, B.F., Thordarson, T., 2010. Tephra dispersal and eruption dynamics of wet and dry phases of the 1875 eruption of Askja Volcano, Iceland. Bull. Volcanol. 72 (3), 259-278.

Carr, M.J., Patino, L.C. and Feigenson, M.D., 2007. Petrology and geochemistry of lavas. Central America: geology, resources and hazards. 1 565-577.

Chough, S.K., Sohn, Y.K., 1990. Depositional mechanics and sequences of base surges Songaksan tuff ring, Cheju Island, Korea. Sedimentology 37 (6), 1115-1135.

Cioni, R., Gurioli, L., Sbrana, A., Vougioukalakis, G., 2000. Precursory phenomena and destructive events related to the late Bronze Age Minoan (Thera, Greece) and AD 79 (Vesuvius, Italy) Plinian eruptions; inferences from the stratigraphy in the archaeological areas. Geol. Soc. Lond., Spec. Publ. 171 (1), 123-141.

Cole, P.D., Queiroz, G., Wallenstein, N., Gaspar, J.L., Duncan, A.M., Guest, J.E., 1995. An historic subplinian/phreatomagmatic eruption: the 1630 AD eruption of Furnas volcano, São Miguel, Azores. J. Volcanol. Geotherm. Res. 69 (1-2), 117-135.

Cole, P.D., Guest, J.E., Duncan, A.M., Pacheco, J.-M., 2001. Capelinhos 1957-1958, Faial, Azores: deposits formed by an emergent surtseyan eruption. Bull. Volcanol. 63 (2-3), 204.

Coltelli, M., Del Carlo, P., Vezzoli, L., 1998. Discovery of a Plinian basaltic eruption of Roman age at Etna volcano, Italy. Geology 26 (12), 1095-1098.

Corti, G., Carminati, E., Mazzarini, F., Garcia, M.O., 2005. Active strike-slip faulting in El Salvador, Central America. Geology 33 (12), 989-992.

Costa, A., Martí, J., 2016. Stress Field Control during Large Caldera-Forming Eruptions. Front. Earth Sci. 4 (92)

Costa, A., Dell'Erba, F., Di Vito, M.A., Isaia, R., Macedonio, G., Orsi, G., Pfeiffer, T., 2009 Tephra fallout hazard assessment at the Campi Flegrei caldera (Italy). Bull. Volcanol. 71 (3), 259.

Costa, A., Gottsmann, J., Melnik, O., Sparks, R.S.J., 2011. A stress-controlled mechanism for the intensity of very large magnitude explosive eruptions. Earth Planet. Sci. Lett. 310 (1-2), 161-166.

Costa, A., Suzuki, J.Y., Koyaguchi, T., 2018. Understanding the plume dynamics of explosive super-eruptions. Nat. Commun. 9 (1), 654.

Daugherty, H.E., 1969 Man-Induced Ecological Change in El Salvador. Ph.D. dissertation, University of California, Los Angeles. University Microfilms, Ann Arbor.

De Rita, D., Giordano, G., Esposito, A., Fabbri, M., Rodani, S., 2002. Large volume phreatomagmatic ignimbrites from the Colli Albani volcano (Middle Pleistocene Italy). J. Volcanol. Geotherm. Res. 118 (1-2), 77-98.

De Rosa, R., Frazzetta, G., La Volpe, L., 1992. An approach for investigating the depositional mechanism of fine-grained surge deposits. The example of the dry surge deposits at "La Fossa di Vulcano". J. Volcanol. Geotherm. Res. 51 (4), 305-321.

Dellino, P., La Volpe, L., 1995. Fragmentation versus transportation mechanisms in the pyroclastic sequence of Monte Pilato-Rocche Rosse (Lipari, Italy). J. Volcanol. Geotherm. Res. 64 (3-4), 211-231.

Dellino, P., Isaia, R., La Volpe, L., Orsi, G., 2004a. Interaction between particles transported by fallout and surge in the deposits of the Agnano-Monte Spina eruption (Campi Flegrei, Southern Italy). J. Volcanol. Geotherm. Res. 133 (1), 193-210.

Dellino, P., Isaia, R., Veneruso, M., 2004b. Turbulent boundary layer shear flows as an approximation of base surges at Campi Flegrei (Southern Italy). J. Volcanol. Geotherm. Res. 133 (1), 211-228.

Delmelle, P., Bernard, A., 2000. Downstream composition changes of acidic volcanic waters discharged into the Banyupahit stream, Ijen caldera, Indonesia. J. Volcanol. Geotherm. Res. 97 (1), 55-75.

DeMets, C., 2001. A new estimate for present-day Cocos-Caribbean Plate motion: Implications for slip along the central American Volcanic Arc. Geophys. Res. Lett. 28 (21), 4043-4046.

DeMets, C., Jansma, P.E., Mattioli, G.S., Dixon, T.H., Farina, F., Bilham, R., Calais, E., Mann, P., 2000. GPS geodetic constraints on Caribbean-North America Plate Motion. Geophys. Res. Lett. 27 (3), 437-440.

Denevan, W.M., 1992. Introduction. In: The Native Population of the Americas in 1492 2nd (Ed.), Edited by William M. Denevan. University of Wisconsin Press, Madison, pp. $x v-x l i$.

Dixon, T.H., 1993. GPS measurement of relative motion of the Cocos and Caribbean Plates and strain accumulation across the Middle America Trench. Geophys. Res. Lett. 20 (20), 2167-2170.

Dull, R.A., Southon, J.R., Sheets, P., 2001. Volcanism, ecology and culture: a reassessment of the Volcán Ilopango TBJ eruption in the southern Maya realm. Lat. Am. Antiq. 12 (1), 25-44.

Dull, R., Southon, J., Kutterolf, S., Freundt, A., Wahl, D., Sheets, P., 2010. Did the Ilopango TBJ Eruption Cause the AD 536 Event. AGU Fall meeting, Abstracts.

Funk, J., Mann, P., 2009. Cenozoic tectonics of the Nicaraguan depression, Nicaragua and median Trough, El Salvador, based on seismic-reflection profiling and remote-sensing dataCenozoic tectonics of the Nicaraguan depression. GSA Bull. 121 (11-12), 1491-1521. 
Garibaldi, N., Tikoff, B., Hernández, W., 2016. Neotectonic deformation within an extensional stepover in El Salvador magmatic arc, Central America: Implication for the interaction of arc magmatism and deformation. Tectonophysics 693 , 327-339.

Golombek, M.P., Carr, M.J., 1978. Tidal triggering of seismic and volcanic phenomena during the 1879-1880 eruption of Islas Quemadas volcano in El Salvador, Central America. J. Volcanol. Geotherm. Res. 3 (3-4), 299-307.

Graettinger, A.H., Valentine, G.A., Sonder, I., Ross, P.S., White, J.D.L., Taddeucci, J., 2014 Maar-diatreme geometry and deposits: Subsurface blast experiments with variable explosion depth. Geochem. Geophys. Geosyst. 15 (3), 740-764.

Graettinger, A.H., Valentine, G.A., Sonder, I., Ross, P.-S., White, J.L., 2015. Facies distribution of ejecta in analog tephra rings from experiments with single and multiple subsurface explosions. Bull. Volcanol. 77 (8), 66.

Guzmán-Speziale, M., Valdés-González, C., Molina, E., Gómez, J.M., 2005. Seismic activity along the Central America volcanic arc: is it related to subduction of the Cocos plate? Tectonophysics 400 (1-4), 241-254.

Hart, W.J.E., 1981. The Panchimalco tephra, El Salvador. New Brunswick, New Jersey, Rutgers University, Central America. M.S. thesis (101 p).

Hart, W.J.E., Steen-McIntyre, V., 1983. Tierra Blanca Joven Tephra from the AD 260 eruption of Ilopango caldera. Archeology and Volcanism in Central America-The Zapotitán Valley of El Salvador, pp. 15-34.

Hernández, E.W., 2004. Características geotécnicas y vulcanológicas de las tefras de Tierra Blanca Joven de Ilopango, El Salvador. Tesis de maestría, Univ. Politécnica de El Salvador, San Salvador (115 p).

Hernández, E.W., Ferrés, D., Delgado-Granados, H., Pullinger, C. and Gutiérrez de Henríquez, E., 2010. The last 40 ka eruptive cycle of Ilopango caldera deposits: a settlement for the San Salvador Metropolitan Area (El Salvador). A. Abstract volume, International Conference Cities on Volcanoes, Fundación Canaria ITER, Tenerife: pp 56

Hernández, W., Delgado-Granados, H., Nieto, J., 2012. La erupción Tierra Blanca 4 (TB4), Caldera de Ilopango, El Salvador. Ministerio de Medio Ambiente y Recursos Naturales, Informe inédito (36 p).

Hernández, W., Aguirre-Díaz, G. and Ayala, P., 2015. La erupción Tierra Blanca Joven y la diáspora de los Mayas. Museo Nacional de Antropología David J. Guzmán, V Congreso Centroamericano de Arqueología en El Salvador. José Erquicia y Shione Shibata editores. 238p. ISBN 978-99961-958-0-8: 227-237.

Houghton, B.F., Schmincke, H.-U., 1989. Rothenberg scoria cone, East Eifel: a complex Strombolian and phreatomagmatic volcano. Bull. Volcanol. 52 (1), 28-48.

Houghton, B.F., Smith, R.T., 1993. Recycling of magmatic clasts during explosive eruptions: estimating the true juvenile content of phreatomagmatic volcanic deposits. Bull. Volcanol. 55 (6), 414-420

Houghton, B.F., Smith, R.T., Gilbert, J.S., 2000. Phreatoplinian eruptions. Encyclopedia of Volcanoes, pp. 513-525.

Houghton, B.F., Wilson, C.J.N., Del Carlo, P., Coltelli, M., Sable, J.E., Carey, R.J., 2004. The influence of conduit processes on changes in style of basaltic Plinian eruptions: Tarawera 1886 and Etna 122 BC. J. Volcanol. Geotherm. Res. 137 (1-3), 1-14

Hutton, D.H.W., Reavy, R.J., 1992. Strike-slip tectonics and granite petrogenesis. Tectonics 11 (5), 960-967.

Jochum Klaus, P., Stoll, B., Herwig, K., Willbold, M., Hofmann, A.W., Amini, M., Aarburg, S. Abouchami, W., Hellebrand, E. Mocek, B, Raczek, I., Stracke, A, Alard, O, Bouman, C. Becker, S., Dücking, M., Brätz, H., Klemd, R., de Bruin, D., Canil, D., Cornell, D., de Hoog C.J., Dalpé, C., Danyushevsky, L., Eisenhauer, A., Gao, Y., Snow, J.E., Groschopf, N., Günther, D., Latkoczy, C., Guillong, M., Hauri, E.H., Höfer, H.E., Lahaye, Y., Horz, K. Jacob, D.E Kasemann, S.A., Kent, AJR, Ludwig, T, Zack, T., Mason, P.R.D., Meixner, A., Rosner, M., Misawa, K., Nash, B.P., Pfänder, J., Premo, W.R., Sun, W.D., Tiepolo, M., Vannucci, R., Vennemann, T., Wayne, D., Woodhead, J.D., 2006. MPI-DING reference glasses for in situ microanalysis: New reference values for element concentrations and isotope ratios. Geochem. Geophys. Geosyst. 7 (2).

Kim, G.B., Cronin, S.J., Yoon, W.S., Sohn, Y.K., 2014. Post 19 ka BP eruptive history of Ulleung Island, Korea, inferred from an intra-caldera pyroclastic sequence. Bull. Volcanol. 76 (4), 802.

Kutterolf, S., Freundt, A., Perez, W., Mörz, T., Schacht, U., Wehrmann, H. and Schmincke, H.U., 2008a. Pacific offshore record of plinian arc volcanism in Central America: 1 Along-arc correlations. Geochemistry, Geophysics, Geosystems, 9(2).

Kutterolf, S., Freundt, A. and Perez, W., 2008b. Pacific offshore record of plinian arc volcanism in Central America: 2. Tephra volumes and erupted masses. Geochemistry, Geophysics, Geosystems, 9(2)

LaFemina, P., Dixon Timothy, H., Govers, R., Norabuena, E., Turner, H., Saballos, A., Mattioli, G., Protti, M., Strauch, W., 2009. Fore-arc motion and Cocos Ridge collision in Central America. Geochem. Geophys. Geosyst. 10 (5).

Le Bas, M.J., Le Maitre, R.W., Streckeisen, A., Zanettin, B., Rocks, I.S.o.t.S.o.I., 1986. A chemical classification of volcanic rocks based on the total alkali-silica diagram. J. Petrol. 27 (3), 745-750

Leake, B.E., Woolley, A.R., Arps, C.E., Birch, W.D., Gilbert, M.C., Grice, J.D., Hawthorne, F.C. Kato, A Kisch, H.J., Krivovichev, V.G. 1997. Report. Nomenclature of amphiboles: report of the subcommittee on amphiboles of the international mineralogical association commission on new minerals and mineral names. Mineral. Mag. 61 (2) 295-321.

Lexa, J., Sebesta, J., Chávez, J.A., Hernández, W., Pecskay, Z., 2011. Geology and volcanic evolution in the southern part of the San Salvador Metropolitan Area. J. Geosci. 56 (1), 106-140

Lohse, J.C., Hamilton, W.D., Brenner, M., Curtis, J., Inomata, T., Morgan, M., Cardona, K. Aoyama, K., Yonenobu, H., 2018. Late Holocene volcanic activity and environmental change in Highland Guatemala. Quat. Sci. Rev. 191, 378-392.

Lovell, W.G. and Lutz, C.H., 1995 Demography and Empire. Dellplain Latin American Studies, Number 33. Westview Press, Boulder.
Macedonio, G., Pareschi, M.T., 1991. An algorithm for the triangulation of arbitrarily distributed points: applications to volume estimate and terrain fitting. Comput. Geosci. 17 (7), 859-874.

Macedonio, G., Costa, A., Longo, A., 2005. A computer model for volcanic ash fallout and assessment of subsequent hazard. Comput. Geosci. 31 (7), 837-845.

Mann, P., 2007. Overview of the tectonic history of northern Central America. Geol. Soc. Am. Spec. Pap. 428, 1-19.

Mann, C.P., Stix, J., Vallance, J.W., Richer, M., 2004. Subaqueous intracaldera volcanism, Ilopango Caldera, El Salvador, Central America. In: Rose, W.I., Bommer, J.J., López, D.L., Carr, M.J., Major, J.J. (Eds.), Natural Hazards in El Salvador: Boulder. Colorado, Geological Society of America Special Paper vol. 375, pp. 159-174.

Marti, A., Folch, A., Costa, A., Engwell, S., 2016. Reconstructing the plinian and coignimbrite sources of large volcanic eruptions: a novel approach for the Campanian Ignimbrite. Sci. Rep. 6, 21220.

Martí, J., Groppelli, G., Brum da Silveira, A., 2018. Volcanic stratigraphy: a review. J. Volcanol. Geotherm. Res. 357, 68-91.

Martínez-Díaz, J.J., Álvarez-Gómez, J.A., Benito, B., Hernández, D., 2004. Triggering of destructive earthquakes in El Salvador. Geology 32 (1), 65-68.

Mastin, L.G., 1997. Evidence for water influx from a caldera lake during the explosive hydromagmatic eruption of 1790 , Kilauea volcano, Hawaii. J. Geophys. Res. Solid Earth 102 (B9), 20093-20109.

Mastin, L.G., Guffanti, M., Servranckx, R., Webley, P., Barsotti, S., Dean, K., Durant, A. Ewert, J.W., Neri, A., Rose, W.I., Schneider, D., Siebert, L., Stunder, B., Swanson, G. Tupper, A., Volentik, A., Waythomas, C.F., 2009. A multidisciplinary effort to assign realistic source parameters to models of volcanic ash-cloud transport and dispersion during eruptions. J. Volcanol. Geotherm. Res. 186 (1), 10-21.

Matthews, N.E., Smith, V.C., Costa, A., Durant, A.J., Pyle, D.M., Pearce, N.J.G., 2012. Ultradistal tephra deposits from super-eruptions: examples from Toba, Indonesia and Taupo Volcanic Zone, New Zealand. Quat. Int. 258, 54-79.

McPhie, J., Walker, G.P.L., Christiansen, R.L., 1990. Phreatomagmatic and phreatic fall and surge deposits from explosions at Kilauea volcano, Hawaii, 1790 AD: Keanakakoi Ash Member. Bull. Volcanol. 52 (5), 334-354.

Montero, W., Dewey, J., 1982. Shallow-focus seismicity, composite focal mechanism, and tectonics of the Valle Central of Costa Rica. Bull. Seismol. Soc. Am. 72 (5), 1611-1626.

Morimoto, N., 1989. Nomenclature of pyroxenes. Mineral. J. 14 (5), 198-221.

Orsi, G., D'Antonio, M., Vita, S.d., Gallo, G., 1992. The Neapolitan Yellow Tuff, a largemagnitude trachytic phreatoplinian eruption: eruptive dynamics, magma withdrawal and caldera collapse. J. Volcanol. Geotherm. Res. 53 (1), 275-287.

Pacheco-Hoyos, J.G., Aguirre-Díaz, G.J., Dávila-Harris, P., 2018. Boiling-over dense pyroclastic density currents during the formation of the $\sim 100 \mathrm{~km} 3$ Huichapan ignimbrite in Central Mexico: Stratigraphic and lithofacies analysis. J. Volcanol. Geotherm. Res. 349, 268-282.

Pfeiffer, T., Costa, A., Macedonio, G., 2005. A model for the numerical simulation of tephra fall deposits. J. Volcanol. Geotherm. Res. 140 (4), 273-294.

Pimentel, A., Pacheco, J., Self, S., 2015. The 1000-years BP explosive eruption of Caldeira Volcano (Faial, Azores): the first stage of incremental caldera formation. Bull. Volcanol. 77 (5), 42

Pittari, A., Cas, R.A.F., Edgar, C.J., Nichols, H.J., Wolff, J.A., Marti, J., 2006. The influence of palaeotopography on facies architecture and pyroclastic flow processes of a lithicrich ignimbrite in a high gradient setting: the Abrigo Ignimbrite, Tenerife, Canary Islands. J. Volcanol. Geotherm. Res. 152 (3-4), 273-315.

Protti, M., Guendel, F. and McNally, K., 1995. Correlation between the age of the subducting Cocos plate and the geometry of the Wadati-Benioff zone under Nicaragua and Costa Rica. Special Papers Geological Society of America: 309-309.

Pyle, D.M., 2000. Sizes of volcanic eruptions. In the Encyclopaedia of Volcanoes, (Sigurdsson, H.; Houghton, B.; McNutt, SR; Rymer, H.; Stix, J., editors). Academic Press, London.

Quane, S.L., Russell, J.K., 2005. Ranking welding intensity in pyroclastic deposits. Bull. Volcanol 67 (2), 129-143.

Reimer, P.J., Bard, E., Bayliss, A., Beck, J.W., Blackwell, P.G., Ramsey, C.B., Buck, C.E., Cheng, H., Edwards, R.L., Friedrich, M., 2013. IntCal13 and Marine13 radiocarbon age calibration curves 0-50,000 years cal BP. Radiocarbon 55 (4), 1869-1887.

Richer, M., Mann, C.P. and Stix, J., 2004. Mafic magma injection triggers eruption at Ilopango Caldera, El Salvador, Central America. Spec. Pap. 375 Nat. Hazards El Salvador $175-190$.

Robock, A., 2000. Volcanic eruptions and climate. Rev. Geophys. 38 (2), 191-219.

Roche, O., Buesch, D.C., Valentine, G.A., 2016. Slow-moving and far-travelled dense pyroclastic flows during the Peach Spring super-eruption. Nat. Commun. 7, 10890.

Rolo, R., Bommer, J.J., Houghton, B.F., Vallance, J.W., Berdousis, P., Mavrommati, C. and Murphy, W., 2004. Geologic and engineering characterization of Tierra Blanca pyroclastic ash deposits. Special Papers Geological Society of America: 55-68.

Rose, W.I., Conway, F.M., Pullinger, C.R., Deino, A., McIntosh, W.C., 1999. An improved age framework for late Quaternary silicic eruptions in northern Central America. Bull. Volcanol. 61 (1), 106-120.

Saxby, J., Gottsmann, J., Cashman, K., Gutiérrez, E., 2016. Magma storage in a strike-slip caldera. Nat Commun. 7, 12295

Šebesta, J., 2007. Geomorfología del AMSS y su relación con los movimientos de ladera. Open file report, Czech Geological Survey Prague Oficina de Planificación del Área Metropolitana de San Salvador (OPAMSS): pp 1-40.

Self, S., Sparks, R.S.J., 1978. Characteristics of widespread pyroclastic deposits formed by the interaction of silicic magma and water. Bull. Volcanol. 41 (3), 196.

Siebert, L., Simkin, T., 2002. Volcanoes of the World: an Illustrated Catalogue of Holocene Volcanoes and their Eruptions. Smithsonian Institution, Global Volcanism Program Digital Information Series, GVP-3. http://www.volcano.si.edu/world/. 
ARTICLE IN PRESS

22

D. Pedrazzi et al. / Journal of Volcanology and Geothermal Research 376 (2019) xxx

Sigl, M., Winstrup, M., McConnell, J.R., Welten, K.C., Plunkett, G., Ludlow, F., Büntgen, U., Caffee, M., Chellman, N., Dahl-Jensen, D., 2015. Timing and climate forcing of volcanic eruptions for the past 2,500 years. Nature 523 (7562), 543.

Simkin, T., Siebert, L., 1994. Volcanoes of the. World2nd Ed. Geoscience Press, Tucson.

Smith, J.V., Brown, W.L., 1988. Spectroscopy-IR, Raman, NMR, NQR, EPR, NGR (Mössbauer), XAS, EXAFS, ESCA, XPS, Feldspar Minerals. Springer 244-267.

Smith, V.C., Isaia, R., Engwell, S.L., Albert, P.G., 2016. Tephra dispersal during the Campanian Ignimbrite (Italy) eruption: implications for ultra-distal ash transport during the large caldera-forming eruption. Bull. Volcanol. 78 (6), 45

Sofield, D., 2004. Eruptive history and volcanic hazards of Volcan San Salvador. Geol. Soc. Am. Spec. Pap. 375, 147-158.

Sohn, Y.K., Chough, S.K., 1989. Depositional processes of the Suwolbong tuff ring, Cheju Island (Korea). Sedimentology 36 (5), 837-855.

Solgevik, H., Mattsson, H.B., Hermelin, O., 2007. Growth of an emergent tuff cone: Fragmentation and depositional processes recorded in the Capelas tuff cone, São Miguel, Azores. J. Volcanol. Geotherm. Res. 159 (1), 246-266.

Sonder, I., Graettinger, A.H., Valentine, G.A., 2015. Scaling multiblast craters: General approach and application to volcanic craters. J. Geophys. Res. Solid Earth 120 (9) 6141-6158.

Sparks, R.S.J., Wilson, L., Sigurdsson, H., 1981. The pyroclastic deposits of the 1875 eruption of Askja, Iceland. Philosophical transactions of the Royal Society of London. Series A, Math. Phys. Sci. 299 (1447), 241-273.

Suñe-Puchol, I., Aguirre-Díaz, G.J., Dávila-Harris, P., Miggins, D.P., Pedrazzi, D., Costa, A., Ortega-Obregón, C., Lacan, P., Hernández, W., Gutiérrez, E., 2019a. The Ilopango caldera complex, El Salvador: Origin and early ignimbrite-forming eruptions of a graben/pull-apart caldera structure. J. Volcanol. Geotherm. Res. 371, 1-19.

Suñe-Puchol, I., Aguirre-Díaz, G.J., Pedrazzi, D., Dávila-Harris, P., Miggins, D.P., Costa, A., Ortega-Obregón, C., Lacan, P., Gutierrez, E., Hernández, W., 2019b. Stratigraphic revision of the complete eruptive sequence and recurrence of large explosive eruptions. The Ilopango Caldera Complex. J. Volcanol. Geotherm. Res. 374, pp. 100-119 (E Salvador).
Taddeucci, J., Valentine, G.A., Sonder, I., White, J.D.L., Ross, P.S., Scarlato, P., 2013. The effect of pre-existing craters on the initial development of explosive volcanic eruptions: an experimental investigation. Geophys. Res. Lett. 40 (3), 507-510.

Turner Henry, L., LaFemina, P., Saballos, A., Mattioli Glen, S., Jansma Pamela, E., Dixon, T., 2007. Kinematics of the Nicaraguan forearc from GPS geodesy. Geophys. Res. Lett. 34 (2).

Valentine, G.A., White, J.D.L., 2012. Revised conceptual model for maar-diatremes: Subsurface processes, energetics, and eruptive products. Geology 40 (12), 1111-1114.

Valentine, G.A., Graettinger, A.H., Sonder, I., 2014. Explosion depths for phreatomagmatic eruptions. Geophys. Res. Lett. 41 (9), 3045-3051.

Valentine, G.A., Graettinger, A.H., Macorps, É., Ross, P.-S., White, J.D.L., Döhring, E., Sonder, I., 2015. Experiments with vertically and laterally migrating subsurface explosions with applications to the geology of phreatomagmatic and hydrothermal explosion craters and diatremes. Bull. Volcanol. 77 (3), 15.

Vallance, J., Houghton, B., 1998. The AD 260 Eruption at Lake Ilopango. A complex explosive eruption through a caldera lake. National Science Foundation, Research Proposal, El Salvador.

Weber, H.S., Wiesemann, G. and Wittekindt, H., 1974. Mapa Geológico de la República de El Salvador/Geologische Übersichtskarte der Republik El Salvador 1: 500,000 (after geological maps 1:100000 - 1967-74) Bundesanstalt für Geowissenschaften und Rohstoffe, Hannover; Bundesanstalt für Bodenforschung, (Hannover).

White, J.D.L., Houghton, B.F., 2006. Primary volcaniclastic rocks. Geology 34 (8), 677-680. Wilkie, J.W. and Guadalupe Ortega, J., 1997 Statistical Abstracts of LatinAmerica. 33, the Regents of the University of California, Los Angeles.

Willcock, M.A.W., Cas, R.A.F., Giordano, G., Morelli, C., 2013. The eruption, pyroclastic flow behaviour, and caldera in-filling processes of the extremely large volume $\left(>1290 \mathrm{~km}^{3}\right.$ ), intra- to extra-caldera, Permian Ora (Ignimbrite) Formation, Southern Alps, Italy. J. Volcanol. Geotherm. Res. 265, 102-126.

Williams, H., Meyer-Abich, H., 1955. Volcanism in the Southern Part of El Salvador: With Particular Reference to the Collapse Basins of Lakes Coatepeque and Ilopango. University of California Press.

Please cite this article as: D. Pedrazzi, I. Sunye-Puchol, G. Aguirre-Díaz, et al., The Ilopango Tierra Blanca Joven (TBJ) eruption, El Salvador: Volcano-

stratigraphy and physical char..., Journal of Volcanology and Geothermal Research, https://doi.org/10.1016/j.jvolgeores.2019.03.006 